\title{
Republic of Poland: Financial System Stability Assessment
}

This paper on the Republic of Poland was prepared by a staff team of the International Monetary Fund as background documentation for the periodic consultation with the member country. It is based on the information available at the time it was completed on July 1, 2013. The views expressed in this document are those of the staff team and do not necessarily reflect the views of the government of the Republic of Poland or the Executive Board of the IMF.

The policy of publication of staff reports and other documents by the IMF allows for the deletion of market-sensitive information.

\author{
Copies of this report are available to the public from \\ International Monetary Fund • Publication Services \\ $70019^{\text {th }}$ Street, N.W. • Washington, D.C. 20431 \\ Telephone: (202) 623-7430 • Telefax: (202) 623-7201 \\ E-mail: publications@imf.org Internet: http://www.imf.org
}

\section{International Monetary Fund Washington, D.C.}




\section{INTERNATIONAL MONETARY FUND}

\section{REPUBLIC OF POLAND}

\section{FINANCIAL SYSTEM STABILITY ASSESSMENT}

June 28, 2013

\author{
Approved By \\ Christopher Towe and \\ Mahmood Pradhan \\ Prepared By \\ Monetary and Capital \\ Markets Department
}

This report is based on the work of the Financial Sector Assessment Program (FSAP) mission that visited Poland in February 2013. The FSAP findings were discussed with the authorities during the Article IV Consultation mission in May 2013.

- The FSAP team was led by Luc Everaert (IMF) and Brett Coleman (World Bank) and included Jorge Chan-Lau, Karl Driessen, Yinqiu Lu, Rishi Ramchand, Nancy Rawlings (all IMF), Katia D'Hulster, Andrey Milyutin, John Pollner, Heinz Rudolph, Ignacio Tirado (all World Bank), and external experts David Walker (Canada Deposit Insurance Corporation), Monnie Biety, and Fernando Montes-Negret (independent consultants). The mission met with Minister of Finance Jan Vincent-Rostowski, National Bank of Poland President Marek Belka, Polish Financial Supervisory Authority Chairman Andrzej Jakubiak, Bank Guarantee Fund President Jerzy Pruski, other officials, and representatives from financial institutions and the private sector.

- Poland's key task ahead lies in diversifying its financial system to support economic growth while preserving its stability. Risks have been managed well as the system grew rapidly. It will be important to develop nonbank financial intermediation, prepare for possible further consolidation and exit of financial institutions, especially cooperatives, credit unions, and small banks, while relying less on foreign funding. Addressing these challenges requires enabling regulatory reform and strengthening of the financial oversight framework.

- FSAPs assess the stability of the financial system as a whole and not that of individual institutions. They are intended to help countries identify key sources of systemic risk in the financial sector and implement policies to enhance its resilience to shocks and contagion. Certain categories of risk affecting financial institutions, such as operational or legal risk, or risk related to fraud, are not covered in FSAPs.

- This report was prepared by Karl Driessen. 


\section{CONTENTS}

GLOSSARY

EXECUTIVE SUMMARY

INTRODUCTION

FINANCIAL VULNERABILITIES

A. Foreign Exchange Loans ___ 11

B. Bank Funding _ـ 15

C. Capital Flows___ 17

D. Asset Quality and Nonperforming Loans___ 18

E. Stress Testing___ 20

FINANCIAL SECTOR OVERSIGHT___________________________________ 22

A. Microprudential Supervision ___ 22

B. Macroprudential Policies and Framework ___ 25

C. EU Dimension _ 26

CRISIS MANAGEMENT AND SAFETY NETS____________________ 27

A. Overview__ 27

B. Bank Resolution Framework___ 28

C. Deposit Insurance IADI Assessment ___ 28

DEVELOPMENT AND MARKET STRUCTURE______________________________ 29

BOX

1. Top-Down and Bottom-Up Stress Tests ___ 22

FIGURES

1. Recent Economic Developments, 2008-13 __ 9

2. Total Assets by Sector____ 11

3. Financial System Selected Indicators ___ 12

4. Impaired Loans___ 14

5. Selected Credit Indicators and Attributes___ 15

6. Loan to Deposit Ratio ___ 16

7. Banking System on Balance Open Foreign Currency Position ___ 17

8. Sovereign Bond_Foreign Investor Purchases and Yield___ 18 


\section{TABLES}

1. Financial Soundness Indicators 10

2. Stress Test Parameter Assumptions Under Different Macroeconomic Scenarios

ANNEXES

I. Risk Assessment Matrix 30

II. Observance of IADI Core Principles 


\section{EXECUTIVE SUMMARY}

Poland's financial system appears to be resilient. Skillful policy management and sound fundamentals have allowed the economy to weather the global financial crisis and the Euro Area turmoil. Risk drivers are well known: slow growth abroad and domestically; rising unemployment; and declining residential real estate prices. Vulnerabilities lie in interconnectedness with the euro area and exposure to foreign exchange risk and foreign investors, which in turn may pressure bank funding, especially in the absence of long-term domestic funding sources. The banking system has been profitable and induced to hold high levels of core tier-1 capital.

\section{Stress tests suggest that vulnerabilities are not likely to become systemic, though some pockets of weakness were identified. Although foreign exchange-denominated lending has been curbed, the outstanding stock remains high. Nonetheless, only in the most severe scenarios would some smaller banks fail to meet solvency standards or run into liquidity problems. Contagion risk is limited as there are few direct interbank connections. Credit unions are a weak but small segment of the financial system. Regulatory arbitrage has pushed some consumer finance transactions outside the regulated system, but modifications to the regulation in question, accompanied by better risk management, are likely to stem this phenomenon.}

\section{Securing asset quality has moved up the supervisory agenda, given persistent nonperforming loans and cyclical deterioration in credit quality. A thematic supervisory review of impaired assets is getting under way that should lead to updated regulatory guidance, if warranted. Tax disincentives, income accrual practices, and obstacles to out-of-court restructurings need to be removed to secure rapid progress in addressing the stock of impaired loans. Further improvements in restructuring, accounting practices and the insolvency framework would be helpful. Ongoing regulatory revisions should avoid contributing to rising nonperforming loans: the removal of uniform debt-to-income (DTI) thresholds will need to be accompanied by tighter oversight of bank risk management practices. While the proposed tightening of loan-to-value (LTV) ratios and currency matching of income and borrowing for mortgages are welcome, regulatory LTV ratios should be set below 100 percent. It will be helpful to harmonize the calculation of DTI ratios, and increase oversight of restructured loans through more granular reporting by banks.}

Financial oversight and safety nets have been improving. Poland is broadly compliant with Basel Core Principles for Effective Banking Supervision (BCP), Insurance Core Principles (IAIS), and International Association of Deposit Insurers (IADI) Core Principles. Banking supervision has improved, as the frequency of targeted inspections has increased and onsite/offsite coordination has been enhanced. However, under the Polish legal system it remains difficult to provide the supervisor with sufficient powers, independence, and resources, which is of particular concern considering its expanding mandate. Consultations with banks and other stakeholders in the industry could be further strengthened. The deposit guarantee fund's prospective role in bank resolution-when it becomes the designated resolution agency-will fill an important gap. 
The structure of the financial system will need to evolve in the face of domestic and external pressures. Competition is likely to increase in the commercial and cooperative banking sectors, leading to consolidation and exit of weaker financial institutions. Scarcer foreign funding means that financing requirements to support economic development will have to be met more from domestic sources of finance. Even though mutual and pension funds have become more important, nonbank finance remains embryonic. These structural developments together with impending changes in the regulatory landscape, require a more risk-based and systemic supervisory approach.

Further strengthening of the financial oversight framework is essential. Constraints on supervisory room for maneuver from membership in the European Union (EU) and the implications of the prospective banking union will shift the onus of oversight onto sound risk management. Legislation to set up a state-of-the-art bank resolution framework should be expedited, designating the deposit guarantee fund as the resolution agency and putting a complete suite of resolution tools at its disposal, in line with the FSB's Key Attributes. Similarly, a systemic risk board should be set up as soon as possible at the heart of an explicit macroprudential policy framework. It should provide the opportunity to adopt a supervisory approach to systemic risks and systemic institutions and clarify the objectives and the roles of the respective macroprudential, microprudential, and financial safety net institutions.

\section{Establishing a similar reform momentum to rebalance the financial system toward capital} market development will be important. The authorities should carefully consider the design and parameters of the various pension pillars. For financial market development, pension funds can play an important role as a domestic source of demand for assets. Similarly, robust capital market funding frameworks-including mortgage covered bonds and securitization-can address the funding needs and mitigate the foreign exchange and asset quality risks facing the banking system. A number of recent regulatory initiatives strive to remedy the situation, focusing on improved asset quality, loan transferability, and reviving the mortgage banks. 


\begin{tabular}{|c|c|}
\hline \multicolumn{2}{|l|}{ Key Recommendations } \\
\hline Recommendations & Time-frame $^{1 /}$ \\
\hline $\begin{array}{l}\text { Addressing impaired loans: (i) intensify oversight of credit risk management and } \\
\text { restructuring practices; (ii) standardize and enhance transparency of bank accounting } \\
\text { practices; and (iii) standardize debt-to-income ratio calculation (paras. 17-20). }\end{array}$ & Short-term \\
\hline $\begin{array}{l}\text { Strengthening banking supervision: (i) expand the scope for KNF to issue legally binding } \\
\text { prudential regulations; (ii) allow KNF's Board to delegate administrative and procedural } \\
\text { decisions to its management, increase KNF independence, and address other governance } \\
\text { issues; and (iii) increase KNF flexibility to allocate budgetary and staff resources and } \\
\text { enhance its analytical capabilities (paras. 27-34). }\end{array}$ & $\begin{array}{c}\text { Short-term/ } \\
\text { Medium-term }\end{array}$ \\
\hline $\begin{array}{l}\text { Strengthening credit unions : (i) eliminate the dual supervision; require a solvency ratio of } \\
8 \text { percent in } 5 \text { years; and clarify the governance of the stabilization fund; (ii) develop an } \\
\text { inclusive set of SKOK regulations and apply accounting principles for financial institutions } \\
\text { to SKOKs; and (iii) develop capital rehabilitation plans for financially weak SKOKs (paras. } \\
36-37 \text { ). }\end{array}$ & $\begin{array}{l}\text { Short-term/ } \\
\text { Medium-term }\end{array}$ \\
\hline $\begin{array}{l}\text { Developing sound macroprudential policies : (i) ensure the macroprudential supervisory } \\
\text { law provides for SRB's independence (with a leading role for the NBP), accountability to } \\
\text { Parliament, and power to make recommendations coupled with an "act or explain" } \\
\text { mechanism; and (ii) develop clear macroprudential policy objectives that are distinct from } \\
\text { those of monetary and microprudential supervisory policy (paras. 38-41). }\end{array}$ & Short-term \\
\hline $\begin{array}{l}\text { Improving the bank resolution framework: (i) ensure precedence of administrative } \\
\text { powers over corporate insolvency procedures; (ii) ensure that the creditor claims hierarchy } \\
\text { protects BFG's claims on resources provided for balance sheet "gap filling" measures; and } \\
\text { (iii) include a Tier-1 capital trigger and link the "public interest" trigger to financial stability } \\
\text { (paras. 48-49). }\end{array}$ & Short-term \\
\hline $\begin{array}{l}\text { Improving the deposit insurance system: (i) remove the PBA from the BFG Council; } \\
\text { (ii) ensure adequate funding and capacity, revise and introduce new regulations, and } \\
\text { enhance protocols in light of expanded mandate; and (iii) amend code of conduct to } \\
\text { restrict employment in member institutions to all employees (paras. 50-51). }\end{array}$ & $\begin{array}{c}\text { Short-term/ } \\
\text { Medium-term }\end{array}$ \\
\hline $\begin{array}{l}\text { Strengthening pension reform and capital markets: (i) allow lifecycle strategies in } \\
\text { pension funds, and measure performance of pension funds in relation to the benchmark } \\
\text { portfolio; (ii) amend MCB framework to allow broader issuance and adopt a legal } \\
\text { framework for mortgage securitization; (iii) strengthen enforcement of security interests } \\
\text { and judicial decisions (para. 53-54). }\end{array}$ & Short-term \\
\hline
\end{tabular}

1/ Short term: within one year; Medium term: 1-3 years. 


\section{Glossary}

\begin{tabular}{|c|c|}
\hline AML/CFT & Anti-Money Laundering and Combating The Financing of Terrorism \\
\hline BGF & Bank Guarantee Fund \\
\hline CAR & Capital adequacy ratio \\
\hline CBS & Commission for Banking Supervision \\
\hline CEE & Central and Eastern Europe(an) \\
\hline DVP & Delivery versus payment \\
\hline ESCB & European System of Central Banks \\
\hline EU & European Union \\
\hline FSAP & Financial Sector Assessment Program \\
\hline FX & Foreign exchange \\
\hline GDP & Gross domestic product \\
\hline IAIS & International Association of Insurance Supervisors \\
\hline IFRS & International Financial Reporting Standards \\
\hline IOSCO & International Organization of Securities Commissions \\
\hline KNUiFE & Insurance and Pension Funds Supervisory Commission \\
\hline KPWiG & Securities and Exchange Commission \\
\hline MoF & Ministry of Finance \\
\hline MOU & Memorandum of understanding \\
\hline NBP & National Bank of Poland \\
\hline OECD & Organization for Economic Cooperation and Development \\
\hline OFE & Open pension fund \\
\hline $\mathrm{OMO}$ & Open market operation \\
\hline OTC & Over-the-counter \\
\hline p.a. & Per annum \\
\hline PLN & Polish zloty \\
\hline PTE & Pension management company \\
\hline RTGS & Real-time gross-settlement \\
\hline ROSC & Report on Observance of Standards and Codes \\
\hline SRO & Self-regulatory organization \\
\hline WSE & Warsaw Stock Exchange \\
\hline
\end{tabular}




\section{INTRODUCTION}

1. Poland's economy performed well in a challenging environment. Strong economic fundamentals and sound macroeconomic management played a key role in keeping the economy out of recession through 2012. At the outset of the global crisis, Poland had no notable macroeconomic imbalances: inflation was contained, credit growth moderate, the banking sector well capitalized, and public and external debt at moderate levels. Countercyclical policies and the floating exchange rate regime, together with ample international reserves and the precautionary Flexible Credit Line arrangement with the IMF, helped insulate the economy and supported confidence. As a result, the economy performed well in 2010-12.

\section{Nonetheless, the economy has slowed recently, reflecting a combination of external} factors and weaker domestic demand since early last year (Figure 1). Heightened financial and sovereign tensions in the euro area both directly - through trade links-and indirectly - through confidence-contributed to the weakening. Financial contagion has been limited to a gradual switch of bank funding toward domestic sources. GDP growth slowed to 1.1 percent in 2012Q4 (year-onyear). Polish firms have cut back on hiring, causing unemployment to rise to 10 percent at end-2012. Credit growth (adjusted for exchange rate ranges) decelerated rapidly to 3.4 percent in 2012 from 8.6 percent in 2011, while residential property prices have been gradually declining. High frequency indicators point to continued slack in the early months of 2013. With inflation dropping below the National Bank of Poland's (NBP's) target, muted wage pressure, and weak domestic demand, the Monetary Policy Council (MPC) has cut policy interest rates by a cumulative 200 percentage point since November 2012 to 2.75 percent.

\section{Poland's financial system has been expanding rapidly and remains dominated by-} mostly foreign-owned-banks. Total financial system assets grew from 86 percent of GDP in 2005 to 124 percent of GDP in 2012. Banks account for about 70 percent of financial assets (Figure 2). Foreign-owned banks control about 63 percent of the banking sector's assets. Recently, foreign banks have retrenched somewhat, and deleveraging by foreign owners has led to some consolidation in the sector. The state owns controlling shares in four banks, which together account for about 23 percent of banking sector assets, including Poland's largest commercial bank with a market share of 16 percent. The banking system is not highly concentrated: the top five banks account for about 44 percent of system assets. The share of nonbanks has grown over the same period to 30 percent of financial system assets, with pension and mutual funds playing a key role.

4. The Polish banking system is well capitalized and liquid. In aggregate, capital adequacy reached 14.7 percent by end-2012, 90 percent of which is Core Tier 1 capital (Figure 3 and Table 1). Profits in 2011 and 2012 were historically high, and recommendations restricting dividend payouts aided capital building. Nevertheless, an overhang of FX-denominated mortgages continues to pose risks to asset quality and funding. 


\section{Figure 1. Poland: Recent Economic Developments, 2008-13}

GDP growth continued to slowin Q4, on the back of weak domestic demand, but net extemal demand remained solid.

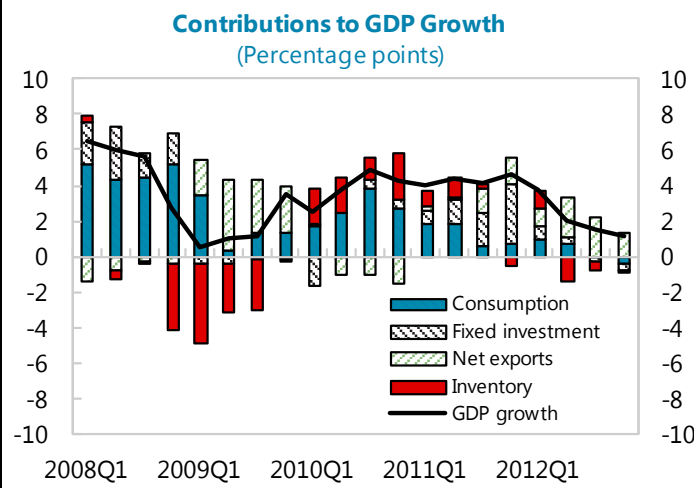

Consumer confidence deteriorates further, and PMI stayed in holding in contractionary territory

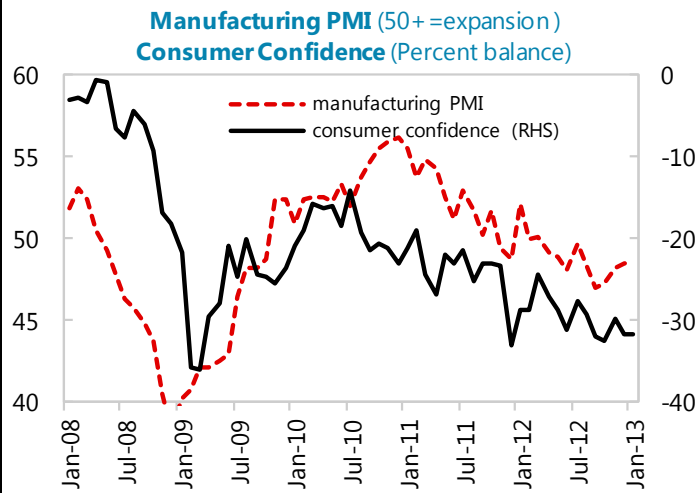

Residential property prices in large cities continued to delcine.

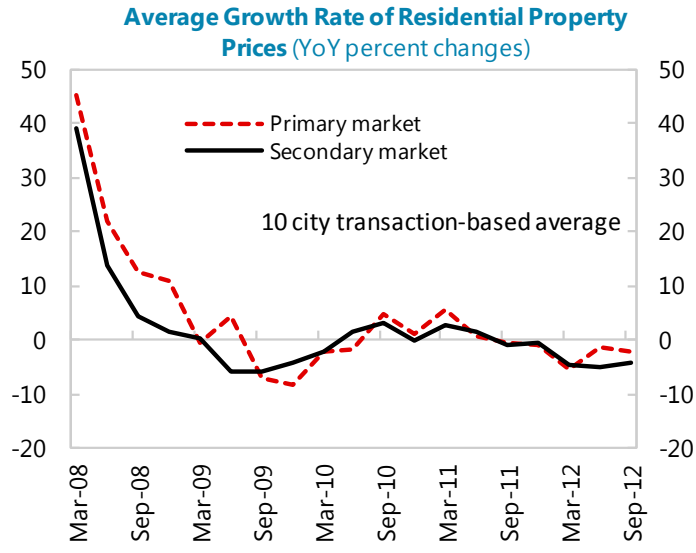

Exports growth has moderated, despite the favorable exchange rate. Imports declined with domestic demand.

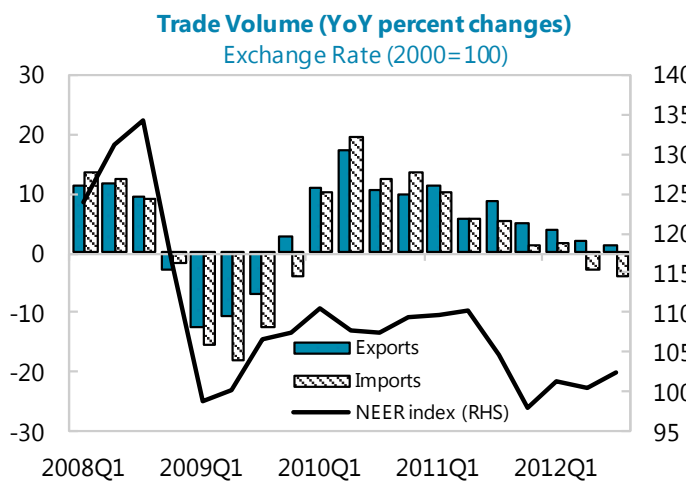

Employment creation is sluggish, and wage pressure is muted.

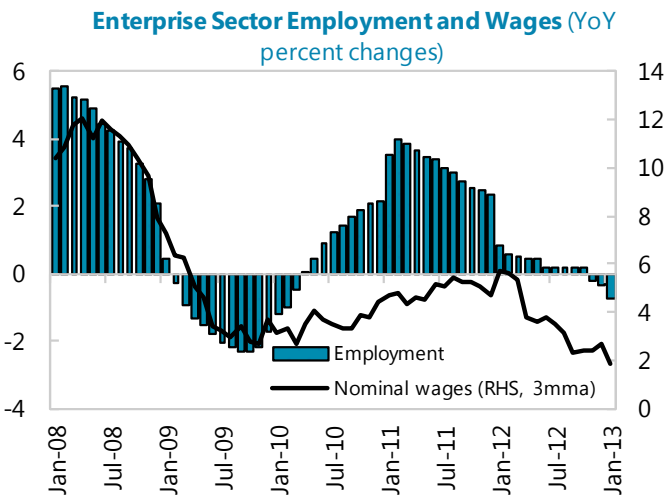

Headline CPI inflation moved below the target inflation rate. Core inflation has also declined.

CPI Inflation

(YoY percent changes)

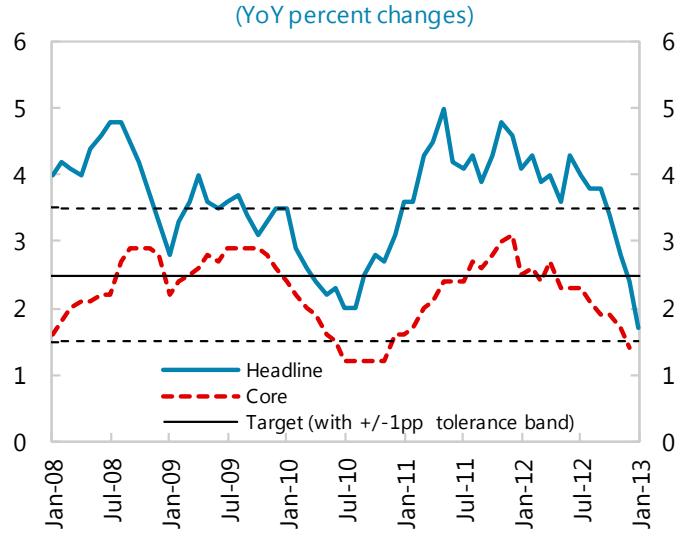

Sources: Haver; Central Statistical Office; NBP; and IMF staff estimates. 
Table 1. Poland: Financial Soundness Indicators

\begin{tabular}{|c|c|c|c|c|c|c|c|}
\hline & 2007 & 2008 & 2009 & 2010 & 2011 & 2012 & $\begin{array}{r}2013 \\
\text { March }\end{array}$ \\
\hline \multicolumn{8}{|l|}{ Capital adequacy $\mathbf{1 /}$} \\
\hline Regulatory capital to risk -weighted assets & 12.0 & 11.1 & 13.3 & 13.9 & 13.1 & 14.7 & 15.4 \\
\hline $\begin{array}{l}\text { Regulatory Tier1 capital to risk -weighted } \\
\text { assets }\end{array}$ & 11.8 & 10.0 & 12.0 & 12.5 & 11.7 & 13.1 & 13.8 \\
\hline NPLs net of provisions to capital & 11.4 & 8.3 & 13.8 & 11.5 & 11.6 & 12.9 & 12.5 \\
\hline Bank capital to assets & 8.0 & 7.5 & 8.1 & 8.2 & 7.8 & 8.7 & 9.0 \\
\hline \multicolumn{8}{|l|}{ Assets composition and quality } \\
\hline NPLs to gross loans (nonfinancial sector) & 5.2 & 4.4 & 7.9 & 8.8 & 8.2 & 8.9 & 8.9 \\
\hline \multicolumn{8}{|l|}{$\begin{array}{l}\text { Sectoral distribution of loans to } \\
\text { nonfinancial sector }\end{array}$} \\
\hline loans to households & 59.3 & 62.0 & 65.3 & 68.0 & 66.4 & 65.7 & 65.8 \\
\hline loans to non-financial corporations & 40.3 & 37.6 & 34.3 & 31.5 & 33.1 & 33.7 & 33.7 \\
\hline \multicolumn{8}{|l|}{ Earnings and profitability } \\
\hline Return on average assets (after tax) & 1.7 & 1.5 & 0.8 & 1.0 & 1.3 & 1.2 & 1.1 \\
\hline Return on average equity (after tax) $1 /$ & 22.4 & 20.7 & 11.2 & 13.3 & 16.1 & 14.1 & 13.3 \\
\hline Interest margin to gross income & 59.4 & 55.7 & 51.9 & 53.0 & 55.8 & 54.8 & 54.5 \\
\hline $\begin{array}{l}\text { Noninterest expenses to gross income } \\
\text { Liquidity }\end{array}$ & 68.7 & 58.4 & 58.5 & 56.0 & 54.5 & 54.6 & 55.3 \\
\hline $\begin{array}{l}\text { Liquid assets to total assets (liquid assets } \\
\text { ratio) }\end{array}$ & 17.1 & 17.0 & 20.3 & 20.8 & 19.5 & 21.1 & 21.6 \\
\hline Liquid assets to total short -term liabilities & 24.2 & 25.3 & 29.8 & 31.2 & 28.8 & 31.4 & 32.3 \\
\hline $\begin{array}{l}\text { Sensitivity to market risk } \\
\text { Net open position in FX to capital } 1 /\end{array}$ & 0.6 & 0.0 & 2.7 & 0.3 & -0.3 & 0.1 & -0.1 \\
\hline
\end{tabular}

\section{Credit unions and cooperative banks constitute a small segment of the banking system} but the latter are growing rapidly. Commercial banks are beginning to encroach on their traditional small town and rural territory as they seek domestic expansion. Cooperative banks are operationally less efficient than commercial banks but their capital ratios appear comparable. Consolidation within the sector would provide scope for greater efficiency and competitiveness, provided it takes place in an orderly manner. Regulatory data on credit unions is limited, but the sector is reportedly poorly capitalized.

\section{There is a small unregulated segment of the financial sector catering to a narrow class} of borrowers that do not qualify for bank credit. There are two main business models: one segment provides small consumer loans (up to PLN 1,000) at high interest, while the other provides installment purchase financing. These firms escape the regulatory perimeter because they do not take deposits. However, risks are contained by regulations that effectively prevent Polish banks from establishing subsidiaries that conduct such activities, although foreign firms (banks and nonbanks) have set up such companies in Poland. 


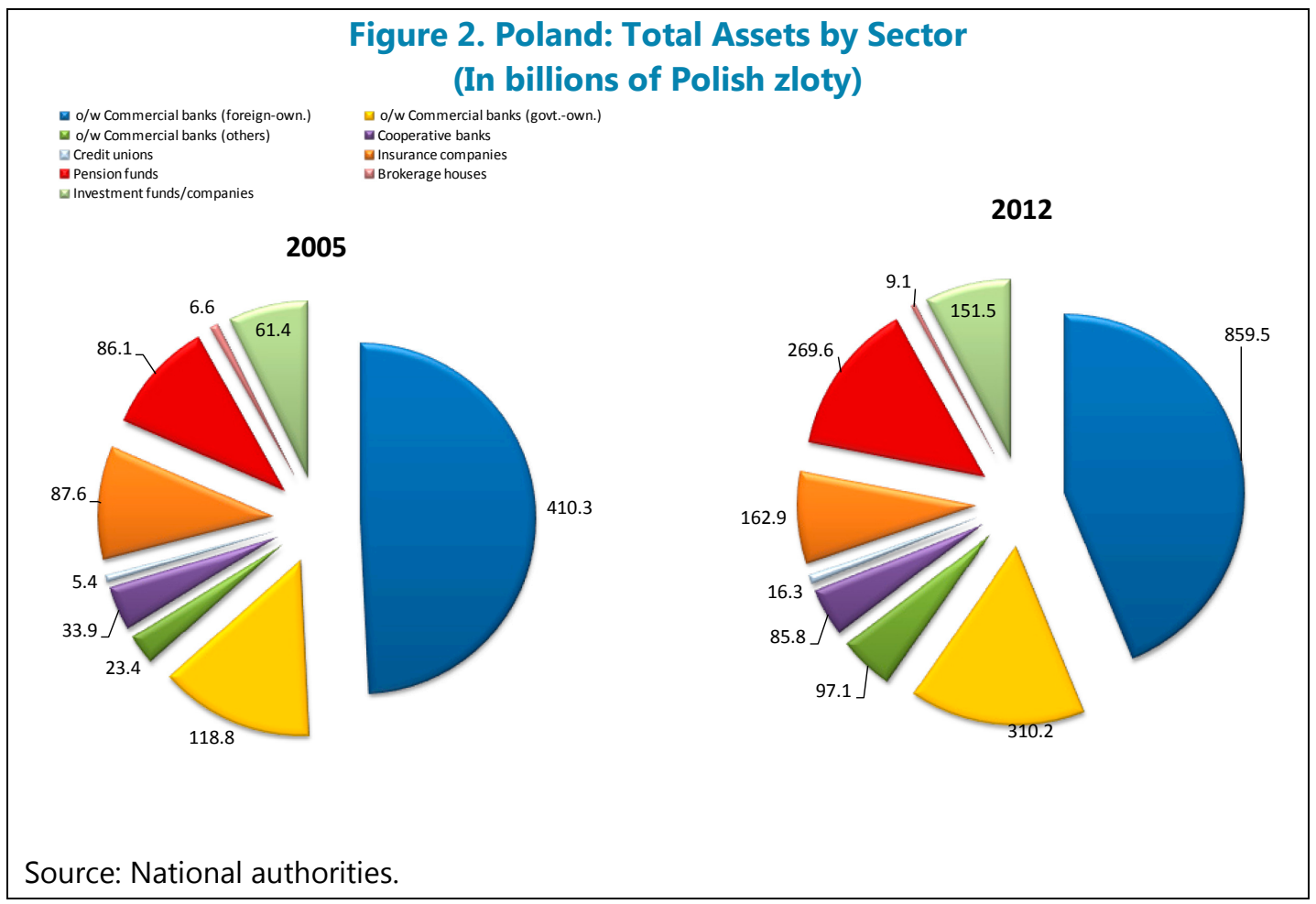

\section{FINANCIAL VULNERABILITIES}

7. The financial system appears to be resilient, though there are vulnerabilities and some weaknesses. Capital adequacy, profitability, and efficiency are high by international standards, though provisioning for residential mortgages is on the low side. While there are pockets of vulnerability, they are not systemic. Main risk drivers are slow economic growth, uncertainty in the euro area, rising unemployment, and falling residential real estate prices (Annex I, Risk Asset Matrix). Vulnerabilities stem from the large outstanding portfolio of foreign exchange loans (some with LTVs well above 100 percent), pressure on bank funding, potential volatility of capital flows, and impaired assets. However, there are mitigating factors: foreign exchange lending has been extended mainly to higher income households, overall household debt is low by international comparison, the duration of foreign exchange hedging has lengthened, the foreign investor base has become more diversified, and banks are relying less on foreign parent funding. Hence, even under severe scenarios, stress tests confirm that the share of assets at risk is small, liquidity sufficient, and contagion risks limited.

\section{A. Foreign Exchange Loans}

\section{Foreign exchange (FX) mortgages increased rapidly through 2008 but have fallen}

since. FX mortgages comprise about 22 percent of the total loan portfolio and more than half of mortgages. The proportion of impaired FX mortgages has been decreasing given the decreasing Swiss interest rates and the practice of converting impaired FX mortgages to PLN mortgages. 
Figure 3. Poland: Financial System Selected Indicators
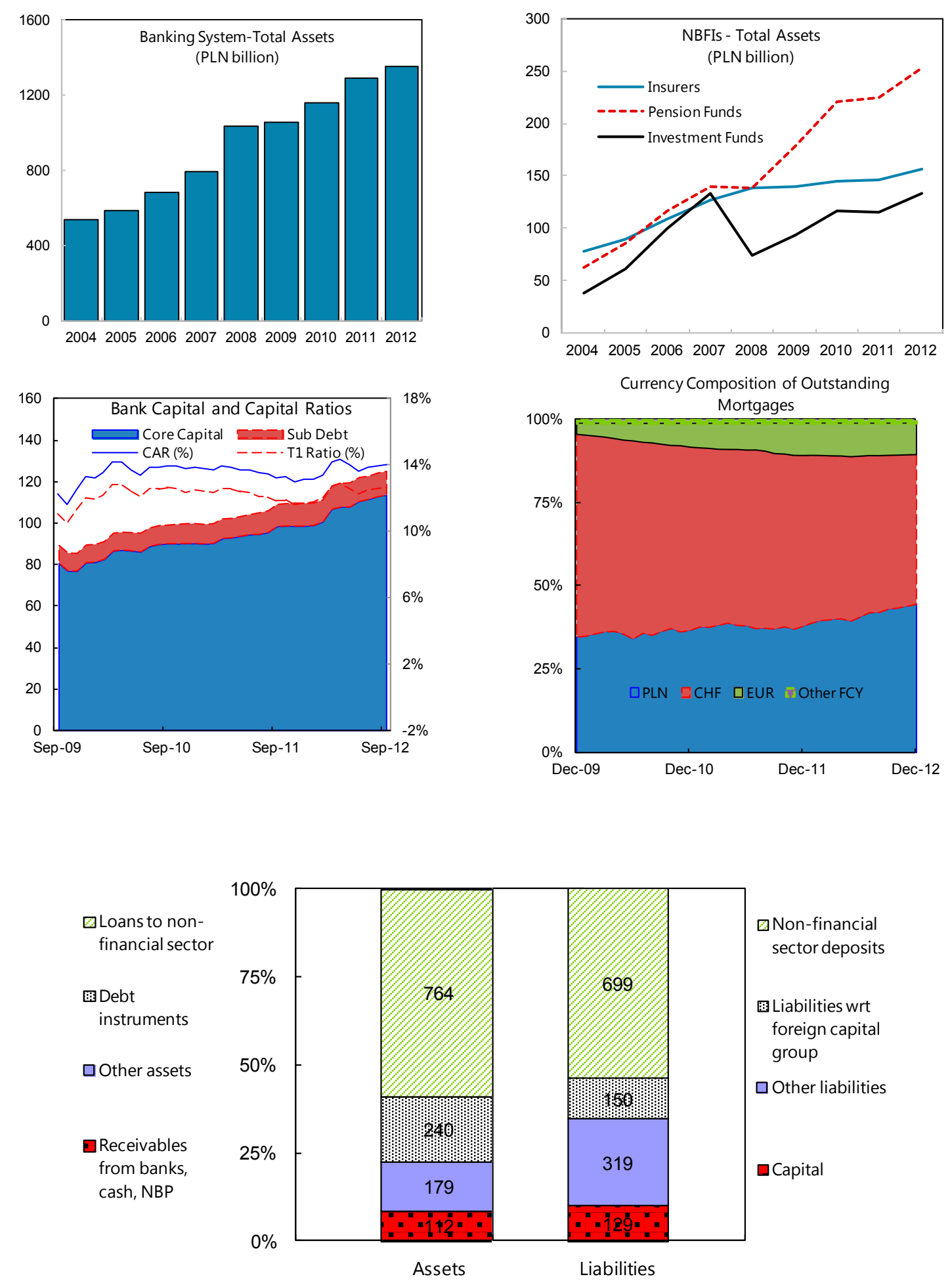

Sources: National Bank of Poland; and KNF. 
Nevertheless, the level of impaired FX mortgages has continued to increase slightly to 1.8 percent as of year-end 2012; for comparison, PLN loan delinquency was 4 percent and the weighted average for total FX and PLN NPLs 2.8 percent of the overall loan portfolio (Figure 4). Inward spillovers from turmoil in the euro area could put pressure on the zloty and adversely affect the loan portfolio, though buffers were built into PLN LTVs; however, increasing unemployment would be the stronger channel of transmission.

9. LTV ratios remain quite high for one-third of the housing portfolio. The majority of loans with LTV's over 100 percent are FX-denominated and in fact, 25 percent of the FX housing portfolio has LTV's over 130 percent. While the average LTV for newly originated loans is about 70 percent, some banks reported they are continuing to offer mortgages at 100 percent LTV. The reserve coverage for impaired housing loans is 48 percent which may be low considering the lengthy recovery process and falling asset prices, raising the potential loss given default (Figures 4 and 5).

\section{Supervisory measures were taken to contain systemic risks associated with mortgage} portfolios. These included tightening of prudential rules in 2006 and 2011, such as lowering the maximum DTI ratio for new FX loans to 42 percent and increasing risk weights on these loans to 100 percent. Authorities are tightening regulatory LTV requirements for all mortgage loans; however, requirements regarding DTI thresholds were removed. Changes also prohibit FX loans to clients without adequate FX income. While many of these proposed revisions will strengthen underwriting of mortgages, the amendment would benefit from some fine tuning. As a result of these measures, new foreign exchange lending has ground to a halt, proving their effectiveness. To guard against risk embedded in the remaining outstanding stock of FX loans, capital buffers are being relied upon, which are for the most part sufficient (see section E). 


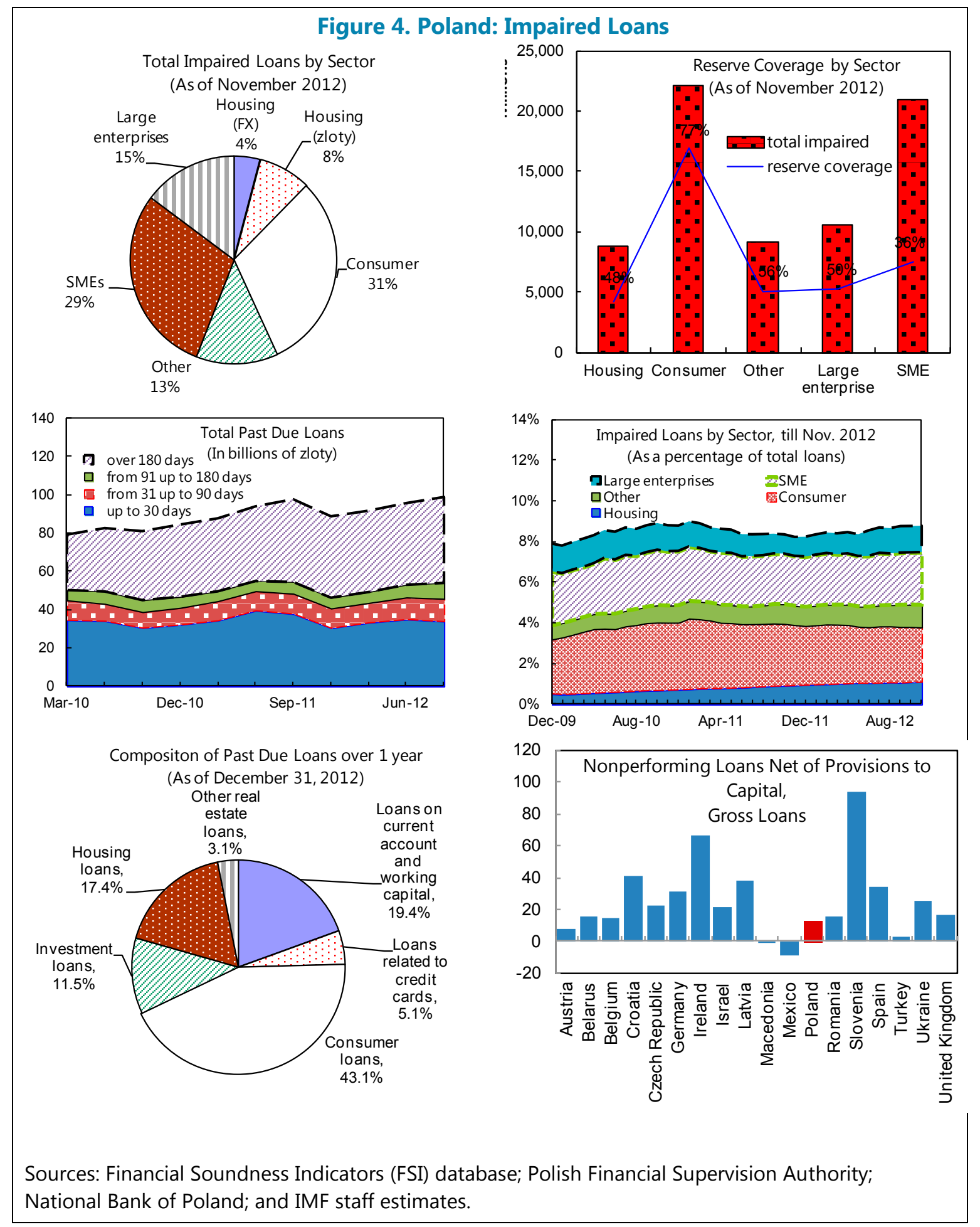




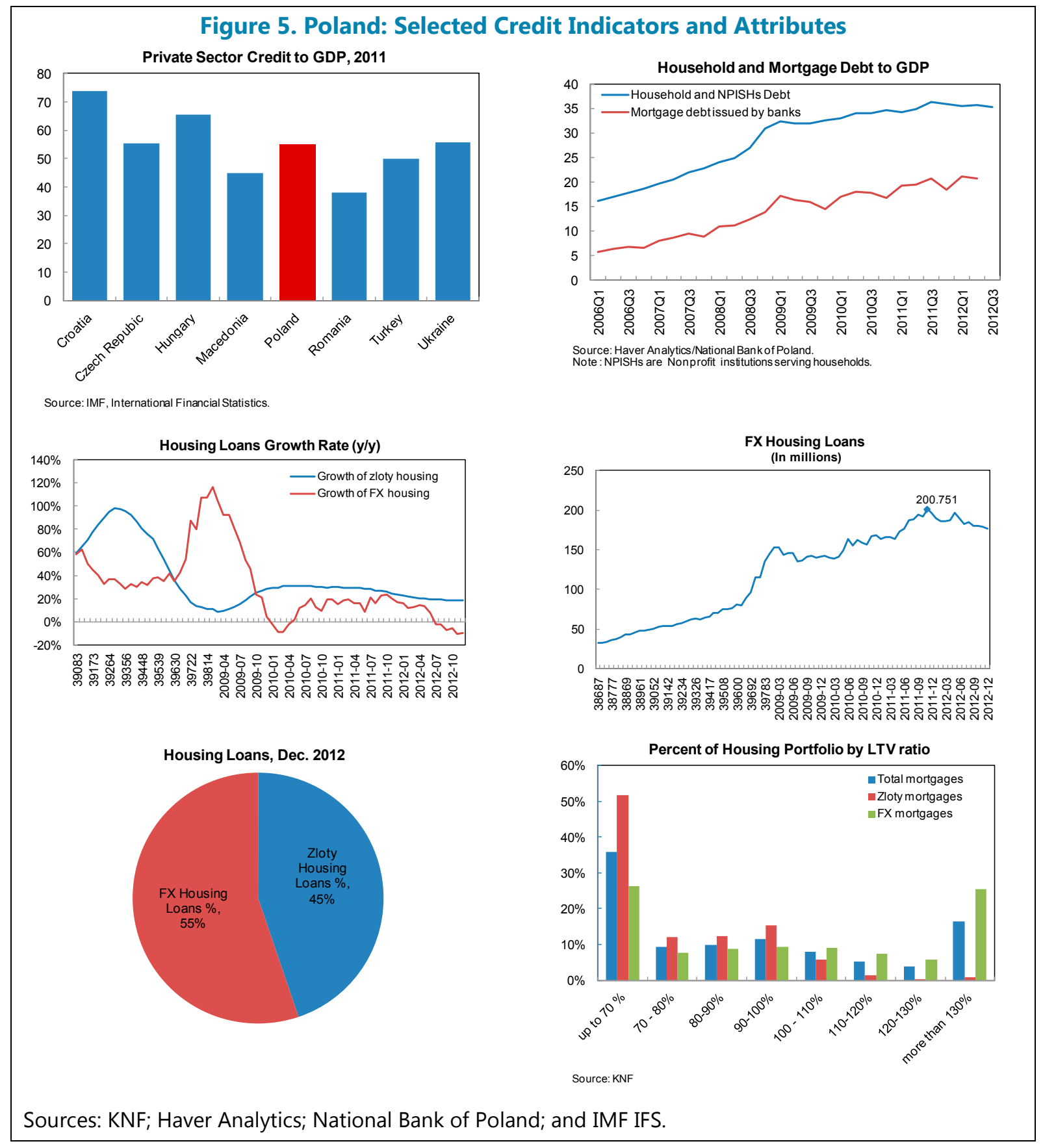

\section{B. Bank Funding}

11. Funding from parent banks is declining in an orderly fashion, and the loan-to-deposit ratio has remained stable in the post-global financial crisis period. In the run up to the global financial crisis, increased funding from parent banks to domestic subsidiaries drove this ratio to about 120 percent (Figure 6). Since 2008, the ratio has stabilized, with signs of some decline in 2012. Continued orderly decline of parent funding, increased reliance on domestic deposits and weak credit growth is likely to further reduce the ratio, easing pressures on banks' funding. A flare up of euro area turmoil constitutes a downside risk as it could precipitate sharper deleveraging. 


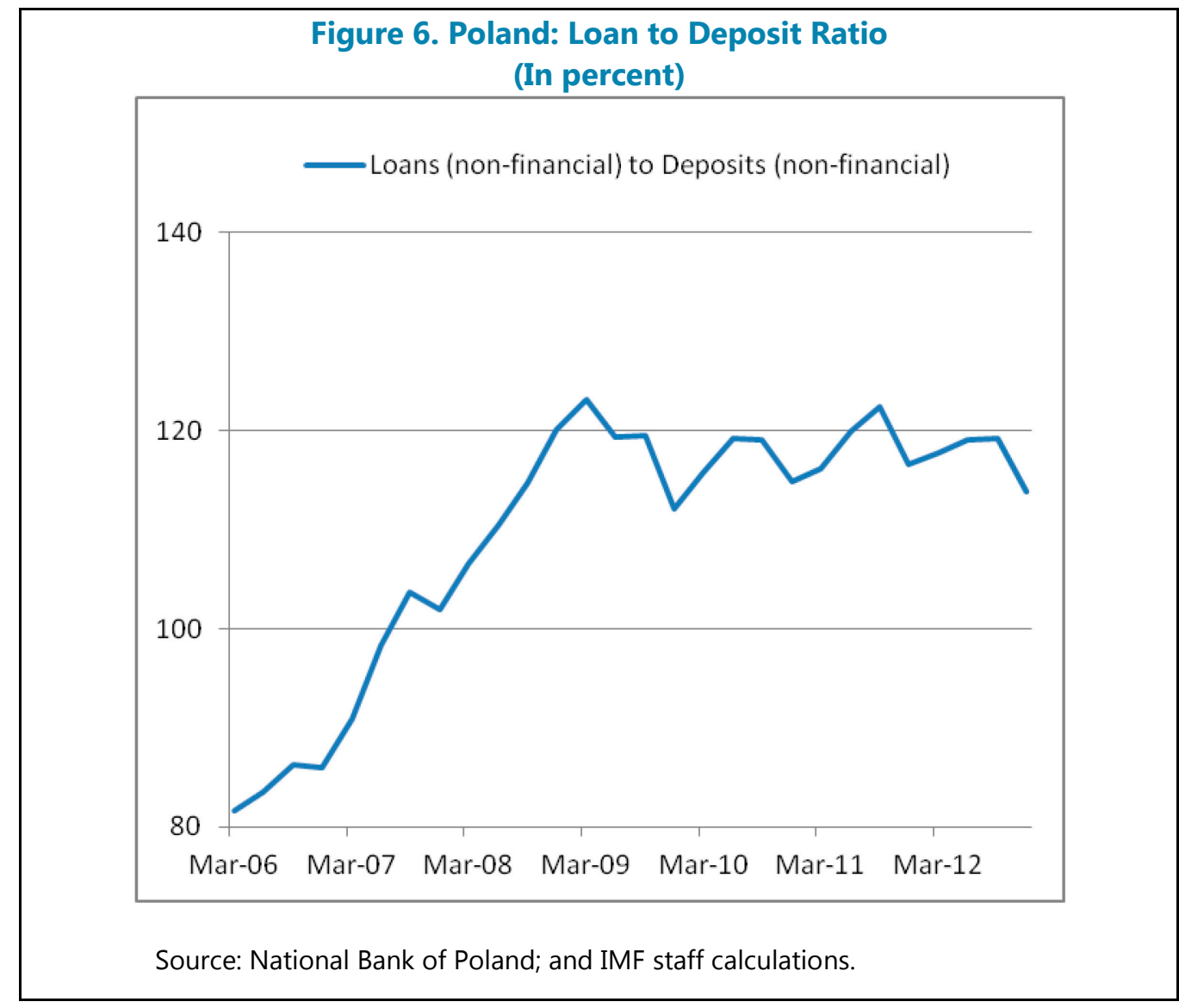

12. Balance sheet currency mismatches, however, require banks to increasingly hedge their exposures-mainly using FX swaps-as parent funding declines. At the aggregate level, the on-balance sheet open foreign currency position is about 5 percent of total commercial bank assets (Figure 7). Hedging needs are declining as new issuance of FX mortgages has drastically slowed, and principal is being repaid faster owing to the low level of Swiss franc interest rates. At the same time, increased holdings of zloty assets by foreign investors support supply of hedging instruments.

\section{Net stable funding ratios are under pressure by the lack of available long-term}

funding. Ahead of the Basel III implementation, the supervisory agency has recommended banks to lengthen the duration of their funding partly to mitigate risks from mortgage portfolios being financed mainly with deposits. However, a shallow domestic investor base, regulatory constraints on pension funds, and the virtual absence of securitization and covered bond markets pose obstacles for progress in this area. Faster deposit growth could mitigate pressure on funding. 
Figure 7. Poland: Banking System on Balance Open Foreign Currency Position

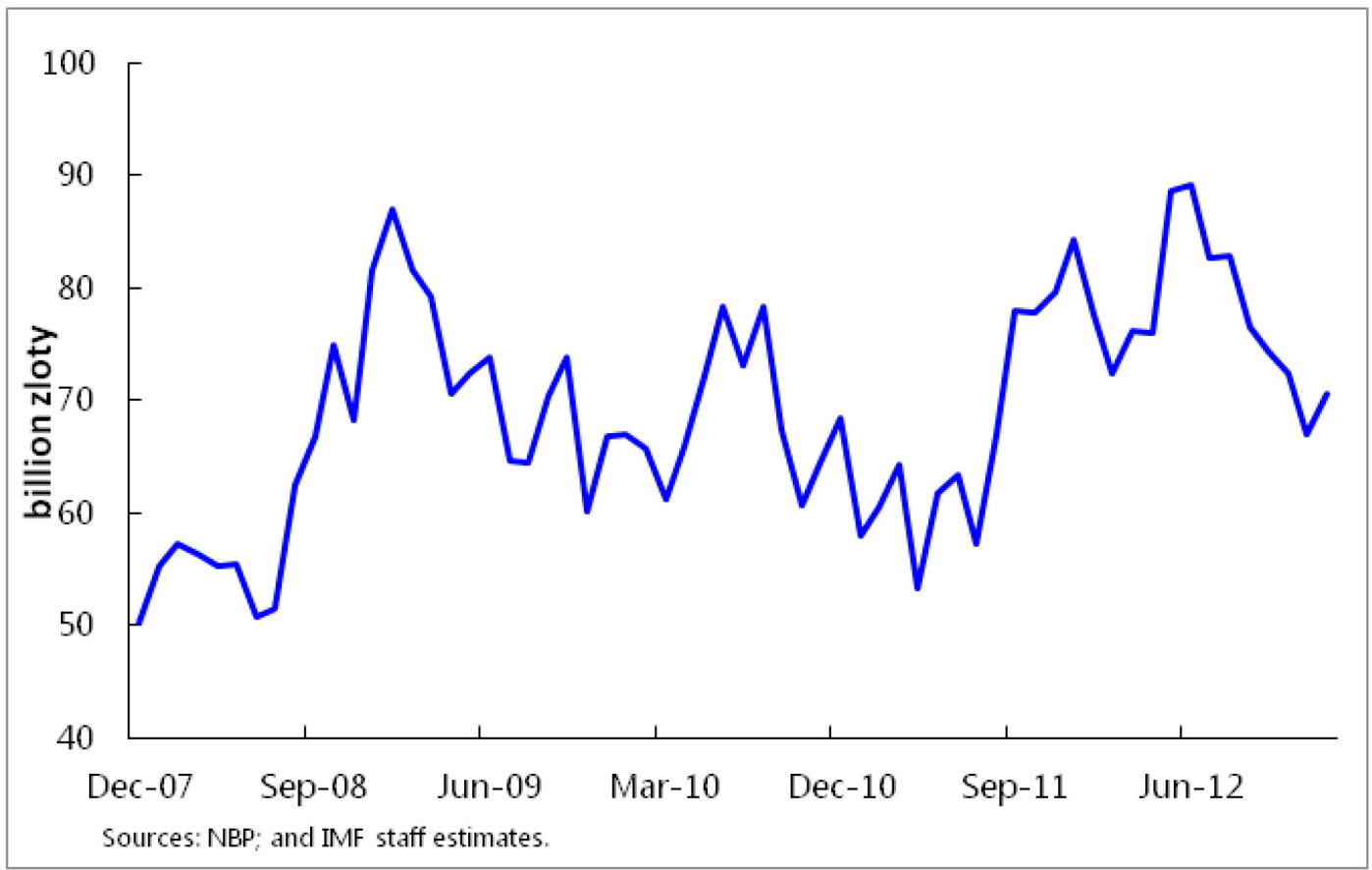

\section{Capital Flows}

14. The sizeable portfolio inflows into the domestic bond markets since 2009 increase Poland's vulnerability to changes in market sentiment. Nonresidents' share of sovereign bond holdings has risen to 36 percent. Growing demand from foreign investors has driven the 5-year government bond yield even below the NBP's policy rate (Figure 8). Foreign investors are drawn to Poland for its relatively deep and liquid government securities market, which enables them to take positions not just on Poland but indirectly on the region as well. However, this attractiveness makes the Polish bond market vulnerable to sudden shifts in risk appetite.

\section{A sharp and persistent unwinding of foreign investors' positions would affect the} banking system through the exchange rate and bond prices. Zloty depreciation associated with capital outflow would lead to liquidity strains in banks with FX-denominated loan portfolios. In addition, the decline in value of government bonds as a result of a sell-off would have negative valuation effects on parts of banks' balance sheets subject to mark-to-market valuation. Moreover, foreign bond investors are important counterparts for domestic banks in the FX swap markets. The unwinding of their positions in the bond markets could reduce the FX liquidity supply in the FX swap markets, and increase FX hedging costs for domestic banks. 


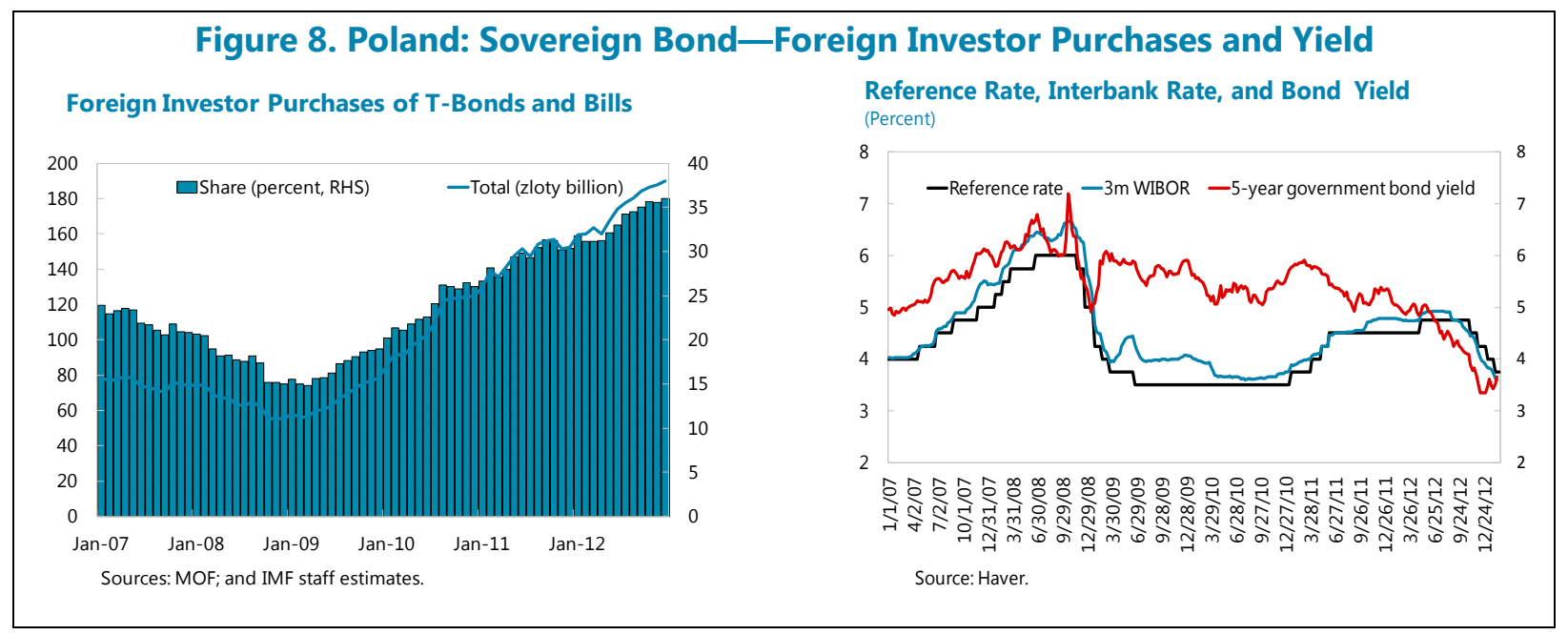

16. The risk of sudden reversal is mitigated by a relatively stable and diversified bond investor base, high domestic liquidity, and sound hedging practices. The main foreign investors are real money investors with relatively long horizons, and Polish sovereign bonds are included in the main global bond indices. The banking sector's systemic liquidity surplus, absorbed by central bank bills (about 100bn zloty at end-2012), provides a cushion against capital withdrawal. In addition, banks are increasingly using long-term CIRS instead of FX swaps to hedge FX risks, reducing their reliance on the counterpart role played by foreign investors. Nevertheless, besides continuing to pursue prudent macroeconomic policies, the authorities should monitor closely the bond investor base and investors' funding and hedging behavior.

\section{Asset Quality and Nonperforming Loans}

17. Asset quality deteriorated rapidly between 2008 and 2009. The increase in impaired loans is most notable for consumer loans, due to lenient underwriting practices and increased competition for market share in this segment before the 2008-09 financial crisis. The corporate sector's capacity to repay bank credit was affected by the crisis and the economic slowdown in 2009, resulting in a doubling of the impaired loan ratio between 2009 and 2010 . The impaired loan ratio stabilized at above 8 percent after 2010, reflecting tightened underwriting standards, credit expansion and sales of impaired consumer loans to third parties. The overall provisioning coverage for impaired loans is 54 percent; however, the ratio varies across sectors and ranges between 36 and 77 percent, suggesting it may be low for certain sectors such as SMEs and housing, especially given the lengthy recovery process, age of portfolios, and falling house prices (Figure 4).

\section{With the economic slowdown and expected rise in unemployment, asset quality is}

likely to deteriorate further. Financial difficulties in and the bankruptcy of a few large construction companies that implemented public infrastructure projects impacted the corporate asset class in 2012 and as such, impaired loans increased by 35 percent-the highest increase for all asset classes. The impaired loan ratio is also expected to increase in residential mortgage portfolio, as this portfolio ages. 
19. Cleaning up bank balance sheets faces a number of obstacles. The majority of loans past due 90 days or more have been past due at least one year and the consumer loan asset class comprises almost half of this stock. The housing stock and corporate stock comprise roughly 20 percent each. While this "overhang" of impaired loans is covered to a large extent by provisions, maintaining them on the balance sheet slows down the resolution process and distorts financial indicators. Banks are legally allowed to accrue high rates of interest on impaired loans for three years after the debtor stops repaying which may provide disincentives for swift resolution. Further, the current tax law restricts the amount of provisions or losses that are tax deductible creating incentives for banks to under-provision. Moreover, limited creditor rights protection makes out of court restructurings for corporate loans unattractive. Finally, mortgage foreclosures and evictions carry social costs and legal challenges, reducing effective recovery values after expenses.

\section{With impaired loans likely to increase and restructuring becoming more pressing, several mitigating actions should be undertaken:}

- Tightening oversight over credit risk management practices: although recently amended guidance on retail lending and proposed changes to guidance on mortgage lending have abolished uniform DTI thresholds for banks, greater responsibility is placed on bank boards for setting such thresholds and oversight of risk management. Regulatory LTV and income requirements for FX loans also have been tightened. Promoting nonbank financial institutions' reporting to the credit bureau would further assist banks in their underwriting decisions given the increase in lending by these institutions.

- Increasing vigilance over restructuring practices: Supervisors should tighten the definition of, and collect more granular data on, restructured loans. Banks may have different definitions of "restructured" loans and are only reporting the total amount of restructured loans. Information should be collected on a monthly basis regarding performance, re-aging, sector composition, amount modified year to date, and accruals and cash revenues. Banks should also be required to disclose their restructuring activities under Pillar 3 requirements.

- Increasing standardization and transparency of accounting practices: With most banks' models for calculating incurred losses and associated provisions following international financial reporting standards (IFRS), there is room for aggressive accounting treatment and thus there may be a risk that levels of provisions are too low or too high given the flexibility in determining the model assumptions. The practice of continuing to accrue income on impaired loans should be reviewed. The Polish Financial Supervision Authority (KNF) intends to conduct thematic reviews of impaired loan portfolios that should lead to amending guidance on impaired loans and provisions, if warranted.

- Improving the insolvency framework to preserve value and lower collection costs: Poland still has a liquidation culture when it comes to insolvency though it is incrementally moving toward a system that encompasses rescue or rehabilitation. Creditors lack an effective voice in the insolvency process. There is no effective supervisory mechanism over insolvency cases. On outof-court restructuring, creditors' rights can be enhanced by adopting an out-of-court code of 
conduct to increase the effectiveness and efficiencies. The market for impaired mortgage loans is still incipient, and one way to increase efficiency is to facilitate the transfer of security right in case of assignment of impaired loans from loan originators to the buyers of impaired loans.

\section{E. Stress Testing}

21. Stress tests indicate that the banking system is resilient to credit and liquidity shocks, as well as contagion risk. ${ }^{1}$ Top-down stress tests conducted by the NBP and the FSAP team show that without mitigating measures, 30 percent of banks may fail to meet minimum capital adequacy ratios under severe macroeconomic scenarios and 10 percent of banks may not have sufficient liquidity under adverse liquidity shortage scenarios. In none of the stress tests did the assets of the affected banks represent more than 10 percent of total banks' assets, with most tests affecting banks representing less than five percent of assets. The result is consistent with the December 2012 regulatory bottom-up stress test conducted by the KNF. In addition, limited interbank lending curtails interconnectedness risk and contagion.

\section{In top-down solvency stress tests undertaken by the NBP, about $\mathbf{3 0}$ percent of the} banks may not meet Basel III capital conservation buffers in the recession scenarios. The stress tests covered the 20 largest banks comprising about 85 percent of the total assets in the banking system. The scenarios included a baseline scenario and three adverse scenarios over a 5-year horizon (Table 2), reflecting the notion that credit losses could be realized with some lags. The erosion of capital buffers is mainly concentrated in the period up to 2015 and affects small banks. In the most severe scenario, total capital needs are about PLN 10.5 billion, equivalent to less than one percent of banking system assets.

\section{The FSAP top-down stress tests and single-shock sensitivity tests also show limited} capital needs. Owing to data confidentiality constraints faced by the authorities, top-down stress tests were performed using data on six representative banks, spanning the distribution of the banking system (Box 1). Sensitivity tests on counterparty, credit, foreign exchange, housing price and interest rate risk suggest the banking system can withstand single adverse shocks. Under the most severe counterparty risk shock, a number of banks representing 14 percent of total assets in the system could breach minimum capital requirements. In the case of credit risk shocks, if one out of five performing loans became impaired, banks representing 30 percent of assets in the system would not meet the minimum CAR. Market risk sensitivity tests had little impact on profits and losses and liquidity.

\footnotetext{
${ }^{1}$ No stress tests were conducted on the non-bank financial system because of its small size, lack of interconnectedness with the banking system, and the absence of complex products.
} 
Table 2. Poland: Stress Test Parameter Assumptions Under Different Macroeconomic Scenarios

\begin{tabular}{lcccccc}
\hline $\begin{array}{l}\text { GDP Growth } \\
\text { (in percent) }\end{array}$ & 2012 & 2013 & 2014 & 2015 & 2016 & 2017 \\
\hline Baseline & 2.2 & 1.7 & 2.3 & 2.9 & 3.4 & 3.5 \\
V-shaped recession & 2.2 & -2.3 & 0.6 & 4.1 & 3.6 & 3.9 \\
U-shaped recession & 2.2 & -0.8 & -0.2 & 2.7 & 3.5 & 3.6 \\
L-shaped recession & 2.2 & -1.3 & -0.7 & 1.9 & 2.3 & 2.2 \\
\hline Unemployment Rate & & & & & & \\
(in percent) & & & & & & \\
\hline Baseline & 9.8 & 10.7 & 11.4 & 11.5 & 11.2 & 10.3 \\
V-shaped recession & 9.8 & 12.2 & 16.0 & 16.7 & 15.8 & 13.8 \\
U-shaped recession & 9.8 & 11.6 & 14.8 & 16.5 & 16.3 & 14.7 \\
L-shaped recession & 9.8 & 11.8 & 15.5 & 17.8 & 18.4 & 17.9 \\
\hline CPI Inflation & & & & & & \\
(in percent) & & & & & & \\
\hline Baseline & 3.8 & 2.6 & 2.3 & 2.0 & 2.4 & 2.7 \\
V-shaped recession & 3.8 & 2.0 & 1.2 & 1.1 & 1.7 & 2.3 \\
U-shaped recession & 3.8 & 2.1 & 1.1 & 0.4 & 1.0 & 1.9 \\
L-shaped recession & 3.8 & 2.0 & 0.8 & -0.3 & 0.0 & 0.7 \\
\hline & & & & & & \\
EUR/PLN & & & & & & \\
\hline Baseline & 4.2 & 4.1 & 4.2 & 4.2 & 4.2 & 4.0 \\
V-shaped recession & 4.2 & 4.5 & 5.1 & 5.0 & 4.8 & 4.5 \\
U-shaped recession & 4.2 & 4.4 & 5.0 & 5.0 & 5.0 & 4.8 \\
L-shaped recession & 4.2 & 4.5 & 5.1 & 5.2 & 5.4 & 5.4 \\
\hline
\end{tabular}

Source: National Bank of Poland; and IMF staff estimates.

24. The results of the $\mathbf{2 0 1 2}$ bottom-up stress tests of the KNF support the findings of the top-down stress tests. No more than two banks, representing about 1 percent of total banking system assets, fall below the regulatory minimum capital ratio in the adverse scenarios. The tests considered a baseline scenario based on the NBP's economic projections; an adverse scenario driven by external shocks and another driven by domestic shocks. The test covered 32 banks accounting for 90 percent of the assets in the system. Adjusting the top-down stress tests for mitigating measures that banks were allowed to adopt in the bottom-up, would yield similar outcomes. 
Box 1. Top-Down and Bottom-Up Stress Tests

The authorities and the FSAP team conducted top-down stress tests using common macro scenarios and compared the results to the authorities' bottom-up stress test.

- The authorities' tests included the 20 largest banks comprising about 85 percent of the total assets in the banking system, and satellite panel data models were used to map the scenarios into credit losses and net income.

- Owing to data confidentiality, the FSAP team's balance sheet top-down stress tests were based on six aggregated representative banks. The representative banks were defined by first dividing the sample of banks into six percentile buckets based on the CAR test distribution at the end of the authorities' stress test. Each representative bank was then constructed by aggregating all the banks in the corresponding bucket.

- The FSAP team also conducted complementary market-based stress tests. These tests were conducted for 13 banks for which market information was available.

- The top-down stress tests were compared with the 2012 bottom-up stress test conducted by the KNF, which covered 32 banks comprising 90 percent of total assets in the banking system. The scenarios differed from those in the top-down tests but were equally severe, and bank reactions to the shocks were accounted for.

\section{The liquidity stress test found that the banking system can withstand liquidity shocks} though asset liquidation could put secondary markets under pressure. Under a simultaneous realization of several shocks, only four banks, with about 10 percent of the total assets in the system, saw their ratio of coverage of fund outflows by liquid assets fall below 100 percent. The forced liquidation of government bills and bonds, however, could lead to some turmoil in secondary markets.

\section{FINANCIAL SECTOR OVERSIGHT}

\section{Impending changes in the regulatory landscape and the structure of the financial} sector require a more risk-based and systemic approach to supervision. ${ }^{2}$ Information from institutions should provide a complete bottom-up risk map of the financial system, which should feed regulatory changes and be integrated in systemic risk management and the overall policy approach to the financial sector.

\section{A. Microprudential Supervision}

27. KNF has limited legal powers imposed by the constitutional framework, forcing it to rely to a large degree on non-legally binding "Recommendations" and "Letters". It runs significant reputational risk if some of these recommendations were systematically circumvented. To mitigate these risks, amendments to the Banking Act should broaden the areas where the KNF can

\footnotetext{
${ }^{2}$ KNF supervises the banking, insurance, pension fund and securities sectors, and oversees payment institutions. It is also responsible for competition, conduct of business, consumer protection and development issues. NBP performs financial stability analysis and data collection. BFG manages Poland's deposit guarantee scheme.
} 
issue resolutions, particularly the powers to supervise permissible risks in bank's activities. Full effectiveness of the KNF may not be achieved, however, without constitutional change.

28. KNF's independence needs to be strengthened further. Having a majority of outside members on the KNF Commission compromises its operational independence and does not guarantee that all its actions are subordinated to the primary objective of safety and soundness of banks. Consideration should be given to modifying the composition of the commission and explicitly stating the primary objective of the KNF in the Financial Market Supervision Act. The prospective establishment of the Systemic Risk Board provides the opportunity to do so and to clearly delineate the respective agencies' responsibilities and instruments.

29. Commissioners are overburdened by work that in other jurisdictions is typically delegated to management, restricting the attention they can devote to high-level matters. The KNF Commission should assess the accumulation of risks in the system, pay attention to the workings of the agency-by endorsing supervisory practices and methodologies-and provide strategic direction. It should receive frequent analyses of emerging risks in the financial system and approve regulations addressing those risks.

\section{Banking supervision}

30. Building on recent progress in implementing EU Directives and BCP recommendations, regulatory gaps on corporate governance, accounting and external audit should be closed. ${ }^{3}$ Specifically, the KNF should obtain the powers to apply fit-and-proper criteria or remove a member of a bank's supervisory board, verify the fitness and propriety of all members of the management board, and reject or rescind the appointment of an external auditor.

\section{Significant improvements have been observed in the frequency of inspections and} onsite/offsite coordination. For 2013, the KNF has planned 4 full-scope and 25 targeted inspections in commercial banks. These consist of 13 horizontal targeted inspections on 7 specific topics and 12 targeted inspections in individual commercial banks. The inspections will cover 86 percent of total assets of commercial banks. The KNF has adopted the practice to inspect the largest commercial banks at least every two years and the others between three and four years.

\section{The Supervisory Review and Evaluation Process (SREP) assessment should be better} integrated into the overall supervisory approach. A full overhaul of the SREP is planned for 2014 to bring it into line with the EBA risk assessment templates and further integrate onsite examination outcomes. Bank level information obtained in the SREP assessment needs to be analyzed and fed into a bottom-up risk map that would form the basis for regulatory initiatives and a more systematic approach to prudential supervision. The Commission's role in this process is essential: it should approve the supervisory methodology and endorse the industry-wide outcomes of the SREP process

\footnotetext{
${ }^{3}$ The February-March 2011 BCP assessment was published in August 2012, and is available here: http://www.imf.org/external/pubs/ft/scr/2012/cr12232.pdf.
} 
and their use for supervisory actions and policies. KNF should also disclose its general supervisory philosophy, including features of the internal supervisory rating systems, the principles underpinning supervisory cycles and inspection frequency, impact assessments and resource allocation.

\section{Interaction with external auditors has become more common since 2011 and should} be further expanded. External auditors expressed concern about limited industry consultation, with the recently released rotation recommendations a case in point. They thought that the KNF had unrealistic expectations on the usefulness of audit work for prudential supervision. Auditors feel that they are being asked by the KNF to go beyond their mandate.

\section{KNF resource allocation must accommodate an expanding supervisory perimeter and} new regulatory challenges, closer realignment to industry risks, and the need to minimize staff turnover. The inclusion of SKOKs in KNF's perimeter of supervision and increase in international and European regulatory requirements has delayed the allocation of additional resources to the commercial banking sector. ${ }^{4}$ Following higher start up costs associated with the first comprehensive on-site inspections which will be conducted in 2013, it is expected that resources allocated to cooperative banks and credit unions will be gradually decreased. Moreover, salary limits for a prolonged period of time, have affected the KNF's ability to attract and retain talent. Frequent salary and benefits benchmarking against the banking industry should be done, and staff turnover rates analyzed. A clear career development path should also be established for KNF staff so that it becomes a more attractive employer.

\section{Insurance supervision}

\section{A recent assessment of the International Association of Insurance Supervisors (IAIS)} Core Principles indicated high observance. Out of the 28 Principles assessed, 14 principles were found to be fully observed, 13 largely observed, and only one partially observed (CP3 on Supervisory Authority). As was the case in the BCP assessment, the weakest area found in the assessment dealt with KNF powers and the resources to exercise them. Moreover, the assessor found that KNF effectiveness would be enhanced by the addition of further staff directed toward insurance supervision, more independence in setting budgets, salaries and organizational structure, and some strengthening of legal protections of its personnel.

\section{Savings and credit union supervision}

\section{Important upcoming changes to the legal framework governing SKOKs will strengthen} their supervisory framework and boost their statutory capital. Although SKOKs represent a small if rapidly growing portion of the financial sector, they could pose systemic risks if the ongoing consolidation process is not managed prudently. Since 2009, the financial trends have been negative due to rising delinquency and operating expenses, falling interest income and the need for additional provisions. SKOKs with weak financial conditions should adopt capital rehabilitation plans

\footnotetext{
${ }^{4}$ In terms of financial assets, the cooperative banks and SKOKs represent only 7 percent of the financial system.
} 
that allow them to meet the solvency ratio in five years or less-it will be difficult to achieve the required 5 percent solvency ratio by January 2014 as currently envisaged, since SKOKs have few sources for increasing capital.

\section{Critical legislation has just been adopted, but further amendments would be desirable.}

The law covers: (i) enhanced KNF supervision tools; (ii) increased scope of information provided by SKOKs; (iii) BFG guarantee for SKOK deposits; (iv) regulation of the SKOKs' liquidity reserve; and (v) modifications to the existing resolution framework. In addition, the law should be amended or regulations drafted to: (i) eliminate the confusion between the roles of NASCU (which "controls") and KNF (which "supervises"); (ii) mandate a solvency ratio requirement of 8 percent, and provide a reasonable transition period; (iii) include member shares as institutional capital only if they are available to absorb losses; and (iv) clarify the powers of KNF and NASCU as they relate to the stabilization fund. A comprehensive set of regulations should be developed to implement the law, and SKOKs should use a simplified chart of accounts, accounting principles, and reporting formats required for financial institutions.

\section{B. Macroprudential Policies and Framework}

38. The Polish authorities are developing a formal macroprudential framework, similar to those recently established elsewhere. Legislation is being drafted to establish a Systemic Risk Board (SRB), which would be the macroprudential decision maker, be responsible for systemic risk identification and analysis, be empowered to request that other agencies take action to limit systemic risk, and be empowered with certain tools to control or limit systemic risk. It will be important for the NBP to take a leading role in the SRB, which can help shield the SRB from political pressures, and ensure that macroprudential policy draws on the central bank's expertise in the analysis of financial and macroeconomic developments. It is essential to safeguard the independence of the SRB and endow it with powers to make recommendations regarding the use of tools, but not to individual financial institutions. Recommendations should be made public and coupled with an "act or explain" mechanism. The law should also require publication of the minutes of SRB's meetings, and establish SRB accountability. The legislation should be enacted without further delay.

\section{The authorities have been active in developing an analytical framework for systemic} issues. Progress is being made in developing an approach to identification of systemic institutions. Efforts should continue in designing such an analytical framework and the SRB should build on the expertise of the three existing agencies (BGF, KNF, NBP) with the aim of producing a list of domestic systemically important financial institutions (D-SIFI's) and a set of risk indicators for these institutions.

\section{On the policy side, Polish authorities have been broadly effective in addressing} sectoral systemic risks. The authorities took measures to address the rapid growth of FX mortgages and related systemic risks, and to manage the high leverage in the retail credit sector during a particular phase of the credit cycle. Requiring additional capital either through higher risk weights for FX mortgages or additional provisioning may be the most effective macroprudential tool 
to reduce demand and curb sectoral risks. A newly amended regulation will remove the requirement for uniform DTI thresholds and lift the income certification requirements for lower loan amounts, with a view to facilitating growth of bank credit for the segment that exited the formal banking system after restrictions were put in place in 2010. Other tools have been deployed to increase capital buffers for all banks.

\section{There is need for clarity on policy objectives and the involvement of the various} prudential and safety net institutions. The authorities need to set clear objectives that are separate from monetary and microprudential supervisory policy objectives. For example, the SRB should not use macroprudential policies to manage the quality of underwriting standards and avoid that its measures jeopardize underwriting quality. In particular, the use of DTIs and LTVs would need to be carefully executed with consideration being given to establishing ceilings for underwriting purposes while reserving space below the ceiling to be used for macroprudential purposes. Conversely, the KNF should not use tools to manage the credit cycle, but focus on the safety and soundness of financial institutions. Reducing risk of systemic institutions would be an example of a precise objective for macroprudential policy. In this regard, the SRB should identify and seek consensus on the policy approach to D-SIFIs, including the use of surcharges, additional supervisory tools, and resolution plans. A complete toolkit of instruments should be identified to pursue macroprudential objectives.

\section{EU Dimension}

42. Poland's regulatory, supervisory, and resolution frameworks are strongly influenced by those of the EU, which are undergoing important changes. Given that Poland's banking system is highly interconnected with the European financial system, arrangements that could strengthen the financial stability at the EU level and, at the same time, represent financial stability interests of Poland (as host country) are highly desirable. When adopted, the CRD IV/CRR, and EU Directives on deposit guarantee schemes and on bank recovery and resolution will need to be transposed into Polish law and regulation. With minimum capital standards and risk weights determined by CRDIV/CRR, it will be important for the KNF to focus its supervision more intensively on banks' risk management practices to preserve the resilience of the banking system. In the area of macroprudential policy, one way to ensure measures taken by the Polish authorities are applied to EU branches operating in Poland is through the "reciprocity" principle agreed with EU institutions (e.g., ESRB). In any case, full use should be made by the policy space provided under CRDIV/CRR to set macroprudential buffers.

\section{The development of the Single Supervisory Mechanisms (SSM) and Banking Union} (BU) may influence the shape of the Polish banking sector. More clarity is needed about the SSM arrangement, and other elements of the prospective Banking Union for Poland to be able to make a full assessment of the implications of the SSM and BU and the benefits and costs of "optingin". Under the SSM, home-host coordination will be replaced by that between the ECB and KNF, which has the potential to improve such cooperation, but at the same time risks downplaying Polish national concerns. As noted in the EU FSAP, it will be important to safeguard the cooperation between home and host authorities and acknowledge the concerns of host supervisors. Moreover, 
as not all home authorities relevant for Poland will be members of the SSM, strengthening of crossborder supervisory and crisis-management colleges remains essential. The agreement on reforming the governance of the European Banking Authority and the confirmation of its role in home-host coordination should help.

\section{Opting in could have benefits in terms of influencing the design of information} sharing and cooperation mechanisms within the SSM, and enhancing credibility. Since Poland is bound by the accession treaty to join the euro zone at some point in the future, opting in at this early stage will give it some, albeit limited influence on the setup of the SSM and BU. An additional benefit would be better access to information and supervisory input on parent banks. From the point of view of investors, opting in could enhance the credibility of Poland as a member of the panEuropean banking union, provided the SSM worked effectively.

\section{However, opting in does not appear to provide benefits in terms of liquidity and} solvency support. Poland is ahead of other prospective SSM members in building a strong, ex ante funded safety net and has a well-tested resolution culture which is being further strengthened.

Given the current shape of the $\mathrm{BU}$, opting in could mean transferring supervisory powers to the $E C B$ without transferring corresponding responsibility for the stability of the national banking system, as access and contributions to a common fiscal safety net remain to be spelled out, as do arrangements for access to ECB liquidity.

\section{CRISIS MANAGEMENT AND SAFETY NETS}

\section{A. Overview}

46. The global financial crisis has prompted Poland to bolster its arrangements for crisis prevention, preparedness and management. In addition, strong anti-crisis measures were taken. At the European Union level, the European Systemic Risk Board (ESRB) was set up, and a multinational, multi-agency MoU on cross-border cooperation was signed; in addition, an array of extraordinary monetary policy and other measures was adopted. Mirroring these developments in Poland, a Financial Stability Committee (FSC) was created, and inter-agency cooperation agreements concluded; the NBP adopted a "confidence package" to alleviate liquidity pressures in domestic markets, allowing longer maturity liquidity and offering new foreign exchange refinancing options.

47. Crisis prevention has taken on greater importance as awareness of the need to manage systemic risk and enhance ex-ante coordination increased. The FSC coordinates the crisis efforts of financial sector agencies, and has coordinated work on a new bank resolution regime. Buffers have been strengthened throughout the financial system: international reserves increased, facilities with foreign central banks arranged, and prudential requirements tightened, including through mandatory profit retention. All safety net participants have created contingency plans, and have undertaken crisis simulations, including two joint exercises. The NBP has worked out the details of its emergency liquidity assistance. Poland has joined crisis management groups for a number of its larger banks. With respect to state solvency support, laws were passed in 2009-2010 specifying the 
conditions for Treasury support and recapitalization of banks. The FSC crisis management contingency plan specifies each institution's responsibilities in case of a threat to financial stability.

\section{B. Bank Resolution Framework}

48. The Polish financial authorities are in the process of adopting a modern bank resolution framework based on the Key Attributes for Effective Banking Resolution. The draft BFG Act includes more flexible tools for, inter alia, starting resolution before a bank reaches full insolvency, allowing partial transfers of a bank's balance sheet to other banks, applying administrative vs. judicial powers, and deploying new debt write-down tools.

49. Additional revisions to the draft BFG Act would strengthen it and assure its effective design and implementation. It should eliminate the use of "open bank" assistance by BFG. If a BFG loan instrument is considered it should only be explicitly part of a resolution process that applies the least cost test; otherwise, such support should be provided by the MoF (solvency) or NBP (emergency liquidity) in systemic situations. Some resolution triggers should be added, such as a tier-1 capital deficit ratio, whereas the "public interest" trigger is overly general and would easily be challenged legally. The authorities need the discretionary power to recast a bank's financial statements and reports according to adjustments deemed prudent. The draft BFG Act should be explicit regarding the new creditor claims hierarchy required for resolution. This is needed to clarify the seniority of BFG claims for contributions made to fill purchase-and-assumption balance sheet gaps when these do not entail any payments to insured depositors. In addition, adding explicit depositor preference would further strengthen the deposit guarantee scheme.

\section{Deposit Insurance IADI Assessment}

50. Poland's deposit insurance system displayed a high degree of conformity with the BCBS-IADI Core Principles for Effective Deposit Insurance Systems. Appendix [X] provides a summary of the assessment. Membership in BFG is compulsory for all domestic banks (and foreign banks which are not already covered by their home country deposit insurance system) and coverage is limited to EUR 100,000 per depositor per bank. The BFG is responsible for collecting deposit insurance premiums; analyzing data on its member banks; reimbursing depositors; and providing financial assistance to member banks on a least cost basis. Depositor reimbursement systems are highly developed and capable of payouts well within the BFG's 20-working day target.

\section{Despite the many accomplishments of the BFG, there are some areas where} deficiencies exist and/or enhancements could be made. Overall governance arrangements for the BFG could be enhanced to better follow best international practices. In particular, the BFG Council includes two representatives of the Polish Bankers Association (PBA), which creates the potential for conflicts of interest. Although the BFG has comprehensive and sufficient funding resources, the need for so many individual funds (e.g., for stability, the deposit guarantee, resolution, and for restructuring banks and cooperative banks) should be reviewed. The BFG should also reassess its fund adequacy in light of EU-mandated coverage increases, the addition of credit unions and the planned introduction of expanded resolution powers; plans are to raise fund adequacy by 
increasing the coverage ratio back to 2007 levels; and, by 2020 to the EC recommended ratio of 1.5 percent of eligible deposits. Although the BFG and those working on its behalf are provided with legal protection, the codes of conduct applied to the BFG and its employees have some gaps which need to be addressed.

\section{DEVELOPMENT AND MARKET STRUCTURE}

\section{Maintaining financial stability while addressing new demands for financial services} requires a shift away from bank-dominated financial intermediation. Developing capital market instruments is essential to build a competitive and safer banking system more efficient at spreading risks and lengthening the maturity of financial savings. Reform in the pension system and in covered bond markets would be helpful,

\section{The authorities should carefully consider the design and parameters of the pension} pillars. The pension system of Poland is based on three pillars. A more efficient organization of the pension fund management industry would ensure lower operational costs and higher expected replacement rates. Lifecycle investment strategies would encourage mandatory pension funds to be invested in portfolios that better address the long-term objectives of future retirees. In the case of voluntary schemes, greater incentives and transparency are essential to allow private agents to take informed decisions, especially against the background of low voluntary private savings and low expected replacement rates. The authorities should consider requiring minimum duration of the fixed-income portfolios of pension funds, which would increase demand for longer-term government securities and encourage private sector companies to issue longer-term bonds. High fees of saving vehicles are a significant barrier to develop voluntary (third pillar) pension schemes in Poland.

\section{Robust capital market funding frameworks can address the funding needs facing the} banking system. A number of recent regulatory initiatives in the mortgage covered bond (MCBs) and securitization area focus on improved asset quality, loan transferability, and reviving the mortgage banks. Universal banks should be allowed to issue MCBs which would be subject to the same terms and conditions as those issued by the mortgage banks. Also, legal and tax obstacles of mortgage rights transfer should be eliminated, and a modern securitization framework established. 


\section{Annex I. Risk Assessment Matrix}

\begin{tabular}{|c|c|c|}
\hline Poland & \multicolumn{2}{|c|}{ Overall Level of Concern } \\
\hline Risk & Relative Likelihood & Expected Impact if Realized \\
\hline $\begin{array}{l}\text { 1. Protracted } \\
\text { period of } \\
\text { slower } \\
\text { European } \\
\text { growth }\end{array}$ & $\begin{array}{l}\text { High } \\
\text { - The adverse impact of the } \\
\text { public and private sector } \\
\text { deleveraging on the real } \\
\text { economy in Europe may be } \\
\text { larger than expected in the } \\
\text { medium term, leading to } \\
\text { sizeable output gaps and } \\
\text { potentially spurring debt- } \\
\text { deflation dynamics. } \\
\text { Job skills could become } \\
\text { obsolete due to long } \\
\text { unemployment spells and } \\
\text { subdued investment, reducing } \\
\text { potential output. }\end{array}$ & $\begin{array}{l}\text { Medium } \\
\text { - Significant trade linkages with Europe would } \\
\text { weaken growth in Poland through lower exports. } \\
\text { - The effects could be partly offset by domestic } \\
\text { demand, as Poland's economy is relatively closed. } \\
\text { - Monetary policy should be further eased as } \\
\text { fiscal space is limited }\end{array}$ \\
\hline $\begin{array}{l}\text { 2. Financial } \\
\text { stress in the } \\
\text { euro area re- } \\
\text { emerges }\end{array}$ & $\begin{array}{l}\quad \text { Medium } \\
\text { - As a result, financial stress } \\
\text { could reemerge in the short term } \\
\text { and bank-sovereign-real } \\
\text { economy links could re-intensify } \\
\text { as a result of stalled or } \\
\text { incomplete delivery of policy } \\
\text { commitments in some peripheral } \\
\text { countries. } \\
\text { - } \quad \text { Strong market pressure on } \\
\text { euro area economies are likely to } \\
\text { reverberate across financial } \\
\text { markets and asset classes. }\end{array}$ & $\begin{array}{l}\text { Medium } \\
\text { - Significant zloty depreciation could lead to } \\
\text { liquidity strains and credit losses in some banks with } \\
\text { FX denominated mortgage portfolios. } \\
\text { - The effects would be mitigated by the strong } \\
\text { and high quality capital position in the banking } \\
\text { sector, and by the moderate stock of these } \\
\text { mortgages relative to the size of the economy } \\
\text { (11 percent of GDP). } \\
\text { - The exchange rate should be allowed to float } \\
\text { freely, but intervention could be used to avoid } \\
\text { abrupt movements. The NBP should provide } \\
\text { liquidity support if needed. }\end{array}$ \\
\hline $\begin{array}{l}\text { 3. Excessive } \\
\text { pace of parent } \\
\text { bank } \\
\text { deleveraging. }\end{array}$ & $\begin{array}{l}\text { Medium } \\
\quad \quad \text { Excessive or uncoordinated } \\
\text { deleveraging by parent banks } \\
\text { would have adverse effects on } \\
\text { credit supply and economic } \\
\text { activity. }\end{array}$ & $\begin{array}{l}\text { Medium } \\
\text { - Excessive deleveraging could result in a credit } \\
\text { squeeze, with adverse implications for growth. } \\
\text { - The effects could be mitigated by reduced } \\
\text { reliance on parent funding, strong balance sheet } \\
\text { and liquidity of the banking system, and the reliance } \\
\text { of the corporate sector on retained earnings to } \\
\text { finance investment. } \\
\text { - The NBP should provide liquidity support }\end{array}$ \\
\hline
\end{tabular}




\begin{tabular}{|c|c|c|}
\hline Poland & \multicolumn{2}{|c|}{ Overall Level of Concern } \\
\hline Risk & Relative Likelihood & Expected Impact if Realized \\
\hline $\begin{array}{l}\text { 4. Emerging } \\
\text { markets } \\
\text { capital flow } \\
\text { reversal }\end{array}$ & $\begin{array}{l}\quad \text { Medium } \\
\text { - Growing demand from } \\
\text { foreign investors of domestic } \\
\text { government bonds could lead to } \\
\text { asset overvaluation and result in } \\
\text { a sharp unwinding of foreign } \\
\text { investors' investment positions In } \\
\text { the short and medium terms } \\
\text { - An unanticipated rise in } \\
\text { global interest could cause } \\
\text { investors to reallocate assets } \\
\text { away from EMs. For example, this } \\
\text { could result from distortions from } \\
\text { unconventional monetary policy } \\
\text { or a fiscal policy shock in the US. }\end{array}$ & $\begin{array}{l}\text { Medium } \\
\text { funding costs for. } \\
\text { - The unwinding of foreign investors' hedging } \\
\text { positions would reduce the liquidity in the FX } \\
\text { derivatives market, increasing banks' hedging costs. } \\
\text { - The risk could be mitigated by a relatively } \\
\text { stable investor base, prudent public debt } \\
\text { management, the strong liquidity of the banking } \\
\text { system, and banks' more prudent approach to } \\
\text { hedging FX risks. } \\
\text { - The exchange rate should be allowed to float } \\
\text { freely, but intervention could be used to avoid } \\
\text { abrupt movements. The NBP should provide } \\
\text { liquidity support if needed. }\end{array}$ \\
\hline $\begin{array}{l}\text { 5. Stronger } \\
\text { than expected } \\
\text { domestic } \\
\text { slowdown, } \\
\text { higher } \\
\text { unemployment, } \\
\text { and declining } \\
\text { real estate } \\
\text { prices }\end{array}$ & $\begin{array}{l}\text { Low } \\
\text { - Continued uncertainty could } \\
\text { further depress confidence } \\
\text { further, leading to a decline } \\
\text { domestic demand and higher } \\
\text { unemployment } \\
\text { This could cause less appetite } \\
\text { for new borrowing, which could } \\
\text { depress housing demand and } \\
\text { lead to further declines in } \\
\text { residential real estate prices. }\end{array}$ & $\begin{array}{l}\text { High } \\
\text { - Stronger than expected domestic slowdown } \\
\text { and higher unemployment could cause larger bank } \\
\text { losses and reduced bank profitability } \\
\text { - The effects could be mitigated by strong capital } \\
\text { buffers in the overall banking system. } \\
\text { - Monetary policy should be further eased, } \\
\text { especially as fiscal space is limited. }\end{array}$ \\
\hline
\end{tabular}




\section{Annex II. Observance of IADI Cores Principles}

\section{SUMMARY, KEY FINDINGS, AND RECOMMENDATIONS}

\section{A. Introduction}

55. As part of the 2013 FSAP Update, the deposit insurance system was assessed against the BCBS-IADI Core Principles for Effective Deposit Insurance Systems. The assessment was conducted by a team of experts from the World Bank and IMF. The team held meetings with officials from the Bank Guarantee Fund-Bankowy Fundusz Gwarancyjny (BFG), the Ministry of Finance (MoF), the National Bank of Poland (NBP), the Polish Financial Supervisory Commission (KNF), the Polish Bankers Association (PBA) and a number of commercial banks. The team found the BFG is Compliant or Largely Compliant with 16 out of 17 applicable Core Principles and Materially NonCompliant with one Core Principle.

56. The BFG was established as a government legislated and administered agency. It is governed by an up to five-member Management Board and overseen by an eight-member Fund Council. Members of the Council include two representatives each selected by the minister of finance and the NBP, one representative of the KNF, and two representatives of the PBA. The BFG Management Board is responsible for managing the fund and day-to-day operations. The Board is composed of a President, Vice-President and from one to three additional members. Information sharing and coordination arrangements are extensive and include legislative provisions for information sharing and coordination in the BFG, Banking and KNF Acts. In addition, a Financial Stability Committee (FSC) is used as a coordination mechanism for primarily financial sector policy issues (with members from the MoF, NBP and KNF). The President of the BFG Management Board attends FSC meetings and will soon become a permanent member.

57. Membership is compulsory for all domestic banks (and foreign banks which are not already covered by their home country deposit insurance system) and coverage is limited to the PLN equivalent of EUR 100,000. As of 30 September 2012, the membership included 619 domestic banks and cooperative banks. There are no foreign bank branch members presently as all foreign bank branches operating in Poland are protected by their home-country deposit insurance system. Under draft legislation being reviewed, cooperative savings and credit unions will be added to the membership of the BFG. In addition to the EUR 100,000 limit per depositor per bank on the level of coverage, the scope of coverage is restricted (e.g., depositors who are deemed professional financial market participants, bank management as well as its shareholders/stakeholders are not covered).

58. The BFG has seen its mandate expand over the years from a "paybox" to a "payboxplus" system. Its present responsibilities include: collecting deposit insurance premiums; inspecting depositor information; analyzing data on its member banks; conducting off-site risk assessment; reimbursing insured depositors; and providing financial assistance to troubled banks using a least cost test criteria. Legislation is under development to expand Poland's financial institution resolution 
regime and as a consequence the BFG would be provided with wider resolution powers. The powers include: the ability to act as a receiver, transfer assets and undertake purchase and assumptions, establish work-out companies, establish bridge institutions, develop resolution plans and resolvability assessments, and include the President of the BFG Management Board on the FSC.

59. The BFG has comprehensive funding resources. There are five funds in existence, one expost (individual bank funds for the protection of guaranteed assets), and four ex-ante funds (an assistance fund for restructuring domestic and cooperative banks, a statutory fund, a reserve fund, and a special fund raised from recoveries from the estates of failed banks). Emergency back-up funding is available from the NBP and MoF. A differential "risk-adjusted" premium system is also in use. BFG funds are sufficient to cover the payout of guaranteed deposits up to the 12th largest bank in Poland (reflecting an ex-ante coverage ratio - the proportion of guaranteed deposits covered - of 1.87 percent). The target fund ratio is 2.72 percent of covered deposits.

60. Depositor reimbursement systems are highly robust and capable of payouts within $\mathbf{2 0}$ working days. Payout processes are highly developed with banks required to report to the BFG depositor data on an ongoing basis, and data quality is monitored by the BFG. A Single Customer View (SCV) system is in use. The payout process is capable of reimbursing depositors within a maximum of 20 working days, and tests and simulations indicate that in many cases payouts could be accomplished in a much shorter time period (within 7 days). Depositors are informed on an ongoing basis about the existence of the BFG and terms and conditions of coverage. The BFG is at the forefront of deposit insurers in using a wide range of communication vehicles (e.g. signage in branches, brochures, web sites, print, video and social media).

\section{B. Preconditions for an Effective Deposit Insurance System}

61. After robust growth last year, the Polish economy is presently feeling the effects of headwinds from Europe. Growth is moderating amid weaker export demand and confidence effects on private investment and consumption, which have combined with lower public investment. Economic activity is projected to slow further. Rising unemployment and tight credit availability are expected to weigh further on household spending. Overall, GDP growth is projected to slow in 2013. Risks around this outlook are on the downside, as a deeper or more protracted slowdown in Europe or a re-intensification of the crisis would affect Poland through substantial trade and financial channels.

\section{Fiscal consolidation in $\mathbf{2 0 1 2}$ and the draft $\mathbf{2 0 1 3}$ budget balances indicate fiscal} adjustment and support for the economy. Despite weaker-than-expected VAT revenues, the general government deficit is projected to drop by $1 \frac{1}{2}$ percentage points to about $3 \frac{1}{2}$ percent of GDP in 2012. The 2013 budget continues the structural consolidation (with measures of some $1 / 2$ percent of GDP) while allowing automatic stabilizers to mitigate the slowdown. These consolidation efforts have supported market confidence and contributed to very favorable financing conditions. 
63. Poland's financial system has been expanding rapidly and remains dominated by banks. The total assets of the financial system grew from 86 percent of GDP in 2005 to 124 percent of GDP in 2012. The financial system is dominated by banks, which account for about 70 percent of assets. At end-2012, there were 70 commercial banks in Poland, of which 61 were subsidiaries or branches of foreign credit institutions, 573 cooperative banks, and 55 credit unions.

64. The banking system is dominated by a handful of foreign-owned banks. They control about 65 percent of the sector's assets - a sizeable proportion, but lower than in the Czech Republic, Hungary, and Slovakia. Foreign banks have retrenched somewhat, and deleveraging by foreign owners has led to some consolidation in the sector. The state owns controlling shares in four banks, which together account for about 22 percent of banking sector assets. The banking system is not highly concentrated; the top five banks account for about 44 percent of system assets.

65. The Polish banking system is well capitalized and liquid. In aggregate, capital adequacy reached 14.7 percent, 90 percent of which is tier-1 capital. Banks' profits in 2011 and 2012 were historically high, and regulations restricting dividend payouts aided capital building. Nevertheless, an overhang of FX-denominated mortgages continues to pose risks to asset quality and funding. Deterioration in the construction sector has also affected loan quality.

66. Regulatory and supervisory efforts have helped improve the resilience of the banking system, but the economic slowdown will pose some challenges for banks. Bank capital buffers have remained comfortable and overall liquidity is ample. However, as the economy has slowed, NPLs have increased and credit growth has eased. Authorities have taken some positive steps to deal with NPLs, such as by encouraging voluntary out-of-court restructuring by banks. Work in establishing a Systemic Risk Board to implement a macroprudential framework and the upgrading of the bank resolution toolkit are also underway.

\section{Sound Governance of Agencies Comprising the Financial Safety Net}

\section{The NBP, KNF and BFG are provided with a range of powers to support financial}

system stability. The central bank, the NBP, performs financial stability analysis and data collection. The KNF is the integrated financial supervisor for the banking, credit union, insurance, pensions, and securities sectors. The BFG manages the deposit guarantee system in Poland and under new legislation being developed would see its role in resolution expanded and become more integrated into the crisis preparedness and management framework. The safety-net participants exhibit operational independence and accountability and have good transparency and disclosure frameworks. The agencies coordinate closely with the MoF.

\section{Poland's regulatory, supervisory, and resolution frameworks are influenced by} developments at the EU level. As a member of the EU, Poland is obliged to comply with EU directives when they come into force. Poland is expected to be in line with the EU Directives on deposit insurance systems, and on bank recovery and resolution. 


\section{Strong Prudential Regulation and Supervision}

69. Oversight of the financial sector is mainly the task of the KNF. It is an integrated supervisor with oversight over the banking, insurance and securities sectors and is responsible for prudential supervision as well as for competition, conduct of business, consumer protection and development issues.

\section{The ongoing modernization of Poland's financial system and challenging} macroeconomic environment pose challenges to the supervisory and regulatory system. NPLs have risen sharply due to the 2008/09 international financial crisis and lenient underwriting standards before 2010. Banks are cleaning up balance sheets but tax disincentives, income accrual practices and impediments in the legal framework have created roadblocks.

\section{The KNF has intensified its supervisory approach and is in the process of revising} underwriting standards. Nevertheless, there are a number of areas that need to be addressed such as deficiencies in the powers of the KNF to issue binding resolutions and the need to enhance the intensity of on-site supervision. Credit and lending policies need to be tightened, and the supervisory authority needs to ensure that bank board oversight and risk management are effective. Monitoring of loan restructuring should be strengthened, and accounting practices for impaired loans improved. The KNF would also benefit from additional resources to deal with the above areas as well as its planned expanded role in supervising credit unions.

\section{E. Well-Developed Legal Framework}

72. Banking laws and regulations in Poland are updated as necessary to ensure that they remain effective and relevant to a changing industry. However, the legal framework needs improvement in areas such as corporate governance, resolution and insolvency. The Banking Act is silent regarding fit-and-proper criteria for members of the banks' supervisory boards. The resolution framework is underdeveloped, and the number of KNF's enforcement actions is relatively low. Finally, major acquisitions by domestic banks require only 30-day ex ante notification to the KNF, and the agency has inadequate power to influence the banking group structures. In sum, the legal framework needs to be improved in a number of key dimensions to ensure sound and consistent requirements in the above-mentioned areas.

\section{Participants in the financial safety net are entitled to protect depositors through a} number of options including depositor reimbursements and financial assistance; but there is room for improvement in the framework for bank resolution. The current framework does not explicitly include flexible resolution tools and relies mainly on corrective action, reorganization, and liquidation phases, the latter deploying the corporate bankruptcy code, which can result in losses of asset value, and requiring up-front payment to insured depositors. New draft legislation (a revised draft BFG Act) includes more flexible tools for, inter alia, starting resolution before a bank reaches full insolvency, allowing partial transfers of a bank's balance sheet to other banks, applying administrative vs. judicial powers, and deploying new debt write-down tools. These are broadly in 
line with the new EU Directives and international best practices espoused by the Financial Stability Board (FSB) and others.

74. Information exchange between the financial system safety net participants is extensive and legally protected for all measures necessary in order to protect depositors and enable safety-net participants to intervene in bank failures. All communications between safety-net participants are subject to confidentiality provisions.

\section{F. Sound Accounting and Disclosure Regime}

75. Accounting and disclosure regimes support the ability of the supervisor and deposit insurer to adequately evaluate the health of individual banks and the banking system as a whole. Audited financial statements of listed companies, banks and similar financial institutions must be published. The accounting and audit profession is self-regulated by the National Chamber of Statutory Auditors and the Commission for Audit Supervision, and there are statutory requirements for auditors to have professional liability insurance. With respect to the BFG, a comprehensive deposit insurance information system has been developed allowing access to detailed information on an ongoing basis. There is a sound process in place to examine and verify the quality of data by the BFG.

\section{KEY FINDINGS AND RECOMMENDATIONS}

\section{The team found the BFG is Compliant or Largely Compliant with $\mathbf{1 6}$ out of $\mathbf{1 7}$} applicable Core Principles and Materially Non-Compliant with one Core Principle. In particular, the team would like to note favorably the many accomplishments of the BFG, including: (i) The successful reimbursement of depositors in 94 bank failures and the provision of financial assistance in 101 bank interventions; (ii) expansion of the deposit insurer mandate from a "paybox" to a "paybox-plus" and recognition of the BFG as a critical component of Poland's financial system; (iii) development of a sound governance framework and information sharing and coordination arrangements with other financial safety-net participants; (iv) creation of a highly developed early warning and risk assessment system to complement its comprehensive and timely depositor data collection and analysis systems; ( $v$ ) wide ranging public awareness activities and innovative tools (e.g., social media) to promote financial literacy and awareness of deposit insurance; and (vi) a well designed depositor reimbursement system capable of prompt payouts.

\section{However, a number of areas were found where deficiencies exist in the deposit} insurance system and financial safety-net arrangements. A corrective action plan to address these areas is proposed (Tables 4 and 5). The major findings are:

- Overall governance arrangements for the BFG could be enhanced to better reflect best international practices. The BFG is governed by an up to five-member Management Board and overseen by an eight-member Fund Council. Members of the Council include two representatives each from the MoF and NBP, one representative of the KNF, and two 
representatives of the PBA. Due to the potential for conflicts of interest with members, it is recommended that the representation of the PBA be removed and consideration be given to involving the PBA through arrangements such as an external advisory committee.

- The BFG has comprehensive and sufficient funding resources although the need for so many individual funds should be reviewed. The BFG currently has five funds in place. In a bank failure, the ex-post fund is used first followed by the BFG's ex ante funds, and if required, supplementary back-up funding is available from the NBP and MoF. While this arrangement is functional and no major problems have been encountered in the past, it is a complex arrangement. And, even under the draft legislative proposals on resolution, the number of funds proposed would remain high. Thus, consideration should be given to rationalizing the number of funds.

- The BFG should also reassess its fund adequacy in light of EU-mandated coverage increases, the addition of credit unions and the planned introduction of expanded resolution powers. The EU-mandated coverage limit increased to EUR 100,000 in 2010; the inclusion of credit unions and the planned adoption of a more comprehensive resolution regime will increase funding requirements. In 2007, the BFG's funds were sufficient to cover the payout of guaranteed deposits up to the 10th largest bank in Poland (reflecting an ex-ante coverage ratio-the proportion of guaranteed deposits_of 2.72 percent). As of 30 September 2012, the increase in the coverage limit lowered the coverage ratio to 1.87 percent leaving BFG ex ante funds (sufficient to cover payouts only up to the 12th largest bank). The team supports BFG plans to raise fund adequacy by increasing the coverage ratio back to 2007 levels; and, by 2020 to the EC-recommended ratio of 1.5 percent of eligible deposits. Moreover, given proposals in draft legislation to extend BFG membership to credit unions and to add significant new resolution powers to its mandate, it would be advisable to review and re-assess fund adequacy in light of these developments going forward.

- Although the BFG and those working on its behalf are provided with legal protection, the codes of conduct applied to the BFG and its employees have gaps that need to be addressed. The BFG, its Management Board and employees, acting in good faith, are not liable for damages in their work. Specific limitations of liability are provided in law for the BFG Management Board and for employees by the general labor code rules. However, codes of conduct restricting employment in member institutions are only applied to the BFG Council and Management Board. Although internal rules require employees to disclose any outside employment, there are no specific statutory prohibitions or restrictions regarding employment in member institutions for BFG employees.

- There are significant deficiencies in Poland's current bank resolution regime, and draft legislation has been developed to address them and expand the BFG's role in resolution. Additional powers planned for the BFG include: the ability to act as a receiver, transfer assets and undertake purchase and assumption transactions, establish bridge institutions, develop resolution plans and resolvability assessments, and include the President of the BFG Management Board on the FSC. The BFG's membership will be expanded to incorporate 
cooperative savings and credit unions. Consequently, the BFG will need to work with its safetynet partners to revise and introduce new regulations, enhance its protocols, and build additional capacity for resolution (e.g., human resources, IT and public awareness initiatives). Information sharing and coordination arrangements with the KNF, NBP and MoF may also need to be updated and enhanced.

\begin{tabular}{|c|c|}
\hline Core Principle & Comments \\
\hline 1. Public policy objectives & $\begin{array}{l}\text { The public policy objectives are formally specified in } \\
\text { legislation and integrated into the design of the BFG. }\end{array}$ \\
\hline 2. Mitigating moral hazard & $\begin{array}{l}\text { The BFG has been provided with design features to } \\
\text { mitigate moral hazard. However, the coverage level is } \\
\text { relatively high and the ability of the supervisory and } \\
\text { regulatory system to mitigate moral hazard could be } \\
\text { enhanced. }\end{array}$ \\
\hline 3. Mandate & $\begin{array}{l}\text { The BFG's mandate is clearly and formally specified in } \\
\text { legislation. }\end{array}$ \\
\hline 4. Powers & $\begin{array}{l}\text { The BFG is provided with the powers necessary to fulfill its } \\
\text { mandate and these are formally specified. }\end{array}$ \\
\hline 5. Governance & $\begin{array}{l}\text { The governance framework is sound and effective. } \\
\text { However, the presence on the Council of members from } \\
\text { the PBA raises conflict of interest issues which are difficult } \\
\text { to fully mitigate with existing arrangements. }\end{array}$ \\
\hline $\begin{array}{l}\text { 6. Relationships with other safety-net } \\
\text { participants }\end{array}$ & $\begin{array}{l}\text { Effective formal information sharing and coordination } \\
\text { agreements have been developed. The BFG is included in } \\
\text { contingency planning exercises conducted for safety-net } \\
\text { participants. The President of the BFG Management Board } \\
\text { will soon become a formal member of the FSC. }\end{array}$ \\
\hline 7. Cross-border issues & $\begin{array}{l}\text { The BFG is in compliance with EU cross-border provisions } \\
\text { and has developed MOUs on information sharing and } \\
\text { coordination with a number of countries. }\end{array}$ \\
\hline 8. Compulsory membership & $\begin{array}{l}\text { Membership in the BFG is compulsory for all domestic } \\
\text { banks and foreign bank branches that are not members of } \\
\text { a home country scheme. Draft legislation under review } \\
\text { will expand membership to cooperative savings and credit } \\
\text { unions. }\end{array}$ \\
\hline 9. Coverage & $\begin{array}{l}\text { Coverage is defined in law, credible, limited and meets the } \\
\text { public policy objectives of the system. }\end{array}$ \\
\hline $\begin{array}{l}\text { 10. Transitioning from a blanket guarantee to } \\
\text { a limited coverage DIS }\end{array}$ & Not applicable. \\
\hline 11. Funding & $\begin{array}{l}\text { The BFG utilizes a hybrid ex-ante and ex-post model that } \\
\text { provides access to a wide range of funding sources. } \\
\text { Funding mechanisms are clearly defined and sufficient } \\
\text { and include access to a number of supplementary funding } \\
\text { mechanisms. However, there are a large number of funds } \\
\text { for varying uses that adds to complexity. }\end{array}$ \\
\hline
\end{tabular}




\begin{tabular}{|l|l|}
\hline 12. Public awareness & $\begin{array}{l}\text { The BFG undertakes a wide variety of activities to promote } \\
\text { public awareness on an ongoing basis. }\end{array}$ \\
\hline 13. Legal protection & $\begin{array}{l}\text { Although overall legal protection arrangements appear } \\
\text { effective, the codes of conduct restricting employment in } \\
\text { member institutions are only applied to the BFG Council } \\
\text { and Management Board. There are no specific statutory } \\
\text { prohibitions or restrictions regarding employment in } \\
\text { member institutions for BFG employees. }\end{array}$ \\
\hline $\begin{array}{l}\text { 14. Dealing with parties at fault in a bank } \\
\text { failure }\end{array}$ & $\begin{array}{l}\text { Relevant authorities in Poland are provided with the } \\
\text { power to seek legal redress against those parties at fault } \\
\text { in a bank failure. }\end{array}$ \\
\hline $\begin{array}{l}\text { 15. Early detection and timely intervention } \\
\text { and resolution }\end{array}$ & $\begin{array}{l}\text { The BFG is well integrated into the early detection and } \\
\text { intervention framework for troubled banks and plays an } \\
\text { important role in providing early warning risk } \\
\text { assessments. But deficiencies exist in the } \\
\text { supervisory/regulatory system identified in the BCP (e.g., } \\
\text { in areas such as corrective actions and on-site supervision) } \\
\text { and resolution framework. }\end{array}$ \\
\hline 16. Effective resolution processes & $\begin{array}{l}\text { The resolution regime has been enhanced over the years } \\
\text { and has in place a number of tools used to facilitate } \\
\text { resolution. However, the current framework is fragmented } \\
\text { and missing important elements such as mechanisms to } \\
\text { provide for asset transfers, receivership powers, purchase } \\
\text { and assumptions, and bridge institutions. Draft legislation } \\
\text { under review would address these deficiencies. }\end{array}$ \\
\hline 17. Reimbursing depositors & $\begin{array}{l}\text { The BFG is capable of giving depositors prompt access to } \\
\text { their insured funds. The ability to conduct on-site } \\
\text { examinations of bank liabilities, the introduction of } \\
\text { standardized data templates and a single customer view } \\
\text { data system will help reduce payout speeds further. }\end{array}$ \\
\hline $\begin{array}{l}\text { The BFG shares in the proceeds of recoveries from the } \\
\text { estate of failed bank. The management of the assets of } \\
\text { the failed bank and the recovery process are guided by } \\
\text { commercial considerations }\end{array}$ \\
\hline
\end{tabular}




\begin{tabular}{|l|l|}
\hline \multicolumn{2}{|c|}{ Table 2. Poland: Recommended Action Plan to Improve Compliance with the BCBS-IADI } \\
Core Principles
\end{tabular}

